\title{
Comments
}

\section{ARCHITECT TORT LIABILITY IN PREPARATION OF PLANS AND SPECIFICATIONS}

The field of law involving architects is young in comparison with the law developed as to the liability of the Doctor and Lawyer; open season on the Architect has just begun. ${ }^{1}$

Although tort liability has changed and expanded since the Second World War, progress in architect tort liability law has not kept up with that in other areas. Apart from contract hability to clients, architect's liability is predicated upon negligence because strict liability is almost never imposed on architects. Also, although the standards defining negligence are reasonably uniform throughout the states, inconsistencies remain in important subsidiary rules concerning the requirement that an injured person be in privity of contract with the architect in order to recover for the latter's negligence and defining the damages which can be recovered without privity. ${ }^{2}$

This Comment considers architect tort liability ${ }^{3}$ for preparation of plans and specifications. ${ }^{4}$ Part I deals with architect hability for negligent ${ }^{5}$

${ }_{1}^{1}$ Allen, Defense of the Architect in Personal Injury Cases, 26 ALA. Law. 201, 217 (1965).

2 Because of this inconsistency, an architect is much more secure from the threat of successful law suits in New York than in California. Compare Inman v. Binghampton Housing Authority, 3 N.Y.2d 137, 145, 143 N.E.2d 895, 899, 164 N.Y.S.2d 699, 704 (1957) (requiring a latent defect absent privity), with Montijo v. Swift, 219 Cal. App. 2d 351, 33 Cal. Rptr. 133 (1963) (requiring neither privity nor a latent defect).

3 Much of the discussion that follows applies to engineers as well as to architects. Most courts treat the legal liabilities or functions of the two professions similarly. See, e.g., Rabinowitz v. Hurwitz-Mintz Furniture Co., 19 La. App. 311, 813, 133 So. 498, 499 (1931); Bell, Professional Negligence of Architects and Engineers, 12 VAND. L. REv. 711 (1959). But see Broyles v. Brown Eng'r Co., 275 Ala. 35, 15I So. 2d 767 (1963) (per curiam).

4 An architect's liability for supervising construction of structures being built in accordance with his plans or for improper issuance of a certificate representing that the job has been properly completed will not be discussed lere. For a general discussion of architect liability for supervision, see Miller, The Liability of the Architect in his Supervisory Function, Forvas, Jan. 1966, at 28. For discussion of improper certificate issuance, see Witherspoon, When Is an Architect Liable? 48 A.B.A.J. 321, 323-24 (1962).

5 Tort liability of the architect can also be based upon fraud. For example, if an architect claims he las unique skill or experience that he does not liave, or if lie gives an opinion that a building of a certain nature can be built for a specified sum when he does not believe that it can be built for that sum, he is liable for fraud. Edward Barron Estate Co. v. Woodruff Co., 163 Cal. 561, 126 P. 351 (1912). In the late nineteenth and early twentieth centuries fraudulent intent as distinguished from mere negligence was usually necessary for recovery from an architect. Allen, supra note 1, at 201. Claims against the architect for fraud are now unusual. See W. SADIER, LEGAL Aspects of Construction 212 
preparation of plans ${ }^{6}$ and specifications, ${ }^{7}$ emphasizing cases where there is no contract privity between the architect and the injured person. Althouglı arclitect tort liability and contract liability to clients clearly overlap, this Comment will generally focus on tort liability because it is in the area of greatest change and difficulty.

Part II argues that strict liability should be imposed upon architects. Existing law, including both architect's liability for negligence and other methods-sucli as insurance and contract provisions-for distributing loss resulting from arclitect errors, does not adequately compensate those who bear the losses initially. Part II both propounds a liopefully workable and just rule for imposing strict liability in certain situations and considers important objections to this rule. Part III of this Comment returns to existing law, in the area of damages, contribution, and indemnity, pointing out the different rules which sloould be followed if strict liability is imposed as suggested.

I

\section{NEGLIGENCE}

Most tort claims against architects involve negligent preparation of plans and specifications. ${ }^{8}$ As with other professions, the architect is liable only if he fails to exercise the reasonable care usually exercised by members of his profession. ${ }^{9}$ Even if his plans result in damage, the architect

(1959). Because of this rarity, and because architect fraud liability involves no distinctive problems of analysis, it will not be given further treatment.

6 "A plan when applied to a building is an architectural drawing representing the horizontal sections of the various floors or stories of the building, the disposition of apartments and walls, with the situation of the doors, windows-in fact represents the different stories as they are to be built, and the whole as it will appear when completed." State ex rel. Silver v. Kendall, 15 Neb. 262, 273, 18 N.W. 85, 90 (1884) (dissent). The courts always refer to "plans" while within the architectural profession "working drawings"

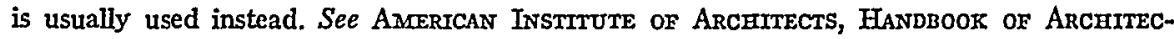
tURAL Practice, bk. III, § 4.01 (8th ed. 1958) [hereinafter cited as Architectural PraCtice]; C. Cowgiti \& B. Smati, Architecturat Practxce 118 (3d ed. 1959).

${ }^{7}$ Specifications show general dimensions of the project, how it will fit the topography, the nature of the subsurface, materials to be used including description of their kind, full dimensions, colors, methods for testing them and nanner of joining the separate nuaterials together. Gilbert v. United States, 1 Ct. Cl. 28, 34 (1863); ARCHrtectural Practice supra note 6, bk. III, \& 5.03. W. JEsSUP \& W. Jessup, LAW aND SPECIFICATIONS FOR ENGINEers

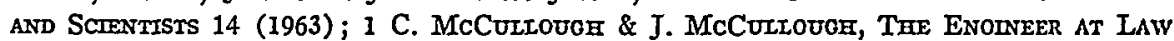
191 (1946). Each specification can raise many questions; for example, the specification for electric wiring can involve questions of location, kind, quality, conformity with local laws, means of supervision suspension, and accessibility to concealed wiring. See Nave v. McGrane, 19 Idaho 111, 125-26, 113 P. 82, 87 (1910).

8 Drake, Adjusting and Defending Claims Under Architects' and Engineers' Professional Liability Policies, 1964 INs. I.J. 466, 467-68.

9 E.g., Looker v. Gulf Coast Fair, 203 Ala. 42, 81 So. 832 (1919); Paxton v. County of Alameda, 119 Cal. App. 2d 393, 398-99, 259 P.2d 934, 938 (1953) (approving trial court 
can escape liability if the damage is found due to a nonnegligent, honest mistake of judgment..$^{10}$ Like doctors, architects can generally set their own standards of conduct; "merely by adopting their own practices"11 they determine the standard by which their conduct is usually judged. ${ }^{12} \mathrm{~A}$ plaintiff must typically prove not only that the architect has deviated from standard architectural practices but also that in deviating from those practices the architect adopted a way of doing things ${ }^{13}$ which was unreasonable for an architect.

The cases rarely discuss whether allowance is made for the kind of community in which the architect practices. One writer claims that an urban practitioner has to be more knowledgeable than a rural one, ${ }^{14}$ but only older cases seem concerned with this point. ${ }^{15}$ Lack of discussion in the cases may be due to the decreasing isolation of rural areas: information about changes in architectural practices is probably as available to the rural architect as to the urban architect. ${ }^{16}$ At most, the community's character should be considered when establishing the standard architectural practice without being reduced to any particular verbal formula ${ }^{17}$ necessary for avoiding error in instructing the jury. ${ }^{18}$

The professional standard represents architectural practice at the time the plans and specifications were prepared. ${ }^{19}$ The architect need not join

instructions); Kortz v. Kimberlin, 158 Ky. 566, 165 S.W. 654 (1914); Chapel v. Clark, 117 Mich. 638, 76 N.W. 62 (1898).

10 See, e.g., Bayshore Dev. Co. v. Bondfoey, 75 Fla. 455, 78 So. 507 (1918); Bayne v. Everlam, 197 Mich. 181, 163 N.W. 1002 (1917); Follansbee Bros. v. Garrett-Cromwell Eng'r Co., 48 Pa. Super. 183 (1911).

11 W. Prosser, Handboot of the LAW of TORTS $\S 32$, at 168 (3d ed. 1964). See generally id. at $164-68$.

12 This is a privilege demied to nonprofessional groups. See id. § 33, at 170 .

${ }^{13}$ See Paxton v. County of Alameda, 119 Cal. App. 2d 393, 406, 259 P.2d 934, 942 (1953).

14 Bell, supra note 3 , at 712 n.5.

15 See, e.g., Hubert v. Aitken, 19 N.Y. St. Rep. 914, 2 N.Y.S. 711 (C.P. 1888), aff'd on reargument, 5 N.Y.S. 839 (C.P. 1889), aff'd mem., 123 N.Y. 655, 25 N.E. 954 (1890).

18 The American Institute of Architects (AIA), to which most architects belong, publishes a constant stream of pamphlets and books relating to new developments, available equally to rural and urban architects. In addition, architects can subscribe to numerous professional journals and magazines.

17 But see Paxton v. County of Alameda, 119 Cal. App. 2d 393, 399, 259 P.2d 934, 938 (1953). The trial court instructed the jury to consider architects "in the same locality." However, there was no indication that local practices would differ from practices elsewhere, nor any indication that "in the same locality" added anything meaningful or significant to the instruction's content.

$18 \mathrm{Cf}$. W. Prosser, silpra note 11, at $\S 32$, at $16 \%$.

19 Correspondence with 25 California architects between October 1, 1966 and November 1,1966 , indicates that 16 of 24 voicing an opinion on the matter believed architecture to be a rapidly advancing field with new techmiques which are difficult to keep up with. The architects were chosen at random from a list of licensed California architects and come 
a minority who have adopted a new material, even if later all architects agree that the new material is superior. ${ }^{20}$

In experimental work, the architect need only use reasonable skill defined as of the date the plans were drawn and is not liable because one year later such a project is no longer experimental. ${ }^{21}$ This properly implies that a house of unusual design will have a higher percentage of defects due to mistakes of judgment than will a house of standard design..$^{22}$ Of course once a new material or technique is accepted, the architect must possess the skill needed to use it. ${ }^{23}$

\section{A. Roles of the Jury and Expert Evidence}

As in most neghigence suits, the jury decides whether the architect was negligent. ${ }^{24}$ Typically, the jury hears a great deal of expert testimony. ${ }^{25}$ A jury can judge the skill of an architect in analyzing stresses only by learing testimony from other architects; ${ }^{26}$ it can learn about standard architectural practices only by hearing architects testify as to those practices. ${ }^{27}$ As in other fields of professional hability, ${ }^{28}$ however, if a layman is as competent as an expert to judge whether or not a particular design created an unusual risk, evidence by experts is inadmissible ${ }^{20}$ because their proof that the defendant followed standard practice would not necessarily show he was not neghigent. Appellate cases are not con-

from firms ranging from one man to over 20 . So it is quite significant that architects are judged as of the time the plans and specifications were prepared. Letters to Jeff Sobel, on file with the California Law Review.

20 See W. SADLER, supra note 5, at 194.

21 Follansbee Bros. v. Garrett-Cromwell Eng'r Co., 48 Pa. Super. 183, 190 (1911).

22 See Major v. Leary, 241 App. Div. 606, 268 N.Y.S. 413 (1934). Hence, custom designers like Richard Kaplan of New York who will "custom design the house of anyone's dreams for a fee of $15 \%$ of total cost," PLAYBOY, Nov. 1966, at 159, probably will have a higher ratio of nonnegligent mistakes of judgment to all mistakes in designing a "multi-level beach house supported by telephone poles," id., than will a designer of "standard" structures.

23 Hubert v. Aitken, 19 N.Y. St. Rep. 914, 2 N.Y.S. 711 (C.P. 1888), aff'd on reargitment, 5 N.Y.S. 839 (C.P. 1889), aff'd mem., 123 N.Y. 655, 25 N.E. 954 (1890).

24 E.g., Willner v. Woodward, 201 Va. 104, 109 S.E.2d 132 (1959).

25 For instance, in one case 468 pages of conflicting expert testimony were compiled to guide the jury in its inquiry. McGuire v. United Bhd. of Carpenters, 50 Wash. 2d 699, 314 P.2d 439 (1957).

26 Similar evidence is usually needed to prove medical negligence. E.g., Sinz v. Owens, 33 Cal. 2d 749, 753, 205 P.2d 3, 5 (1949) (physician); Walter v. England, 133 Cal. App. 676, 680, 24 P.2d 930, 931 (1933) (dentist).

27 Paxton v. County of Alameda, 119 Cal. App. 2d 393, 399, 259 P.2d 934, 938 (1953). 28 See, e.g., Sinz v. Owens, 33 Cal. 2d 749, 753, 205 P.2d 3, 5 (1949) (medicine).

29 E.g., Kenney v. Washington Properties Inc., 128 F.2d 612, 614 (D.C. Cir. 1942); Dewey v. Klines, Inc., 229 Mo. App. 1079, 1086, 86 S.W.2d 622, 626 (1935); Krieg v. Timkin, 102 N.J.L. 307, 309-10, 131 A. 905, 906 (Ct. Err. \& App. 1926); Graham v. Pennsylvania Co., 139 Pa. 149, 158-62, 21 A. 151, 153-54 (1891). 
sistent in indicating what things laymen are capable of determining for themselves; this is probably due to the broad trial court discretion ${ }^{30}$ in determining admissibility of expert evidence. For instance, one court affirmed a finding that laymen were able to decide whether a raised part of a platform, or wide step, presented an unreasonable danger; ${ }^{31}$ another court in approving a lower court's ruling found the issue of whether a step at the end of a vestibule would be seen or tripped over by entering guests

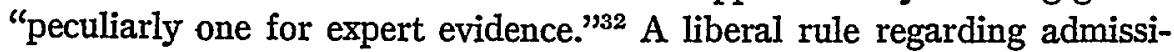
bility of expert testimony should be adopted by courts. Whether a particular design creates an unreasonable risk depends upon the number of injuries associated with it as compared to alternative designs and on the relative costs of each. Such statistical information is hopefully within the knowledge of experts in the field. No design will prevent all injuries. Evidence of the standard practice and of actual injuries caused by that practice is highly relevant and hopefully within the knowledge of experts, and, if they can give such evidence, their testimony should be admitted. The jury would not be bound to decide in accord with weak but uncontradicted expert evidence; but in almost all cases the jury's inquiry would be aided by expert testimony.

\section{B. The Role of Res Ipsa Loquitur}

In some cases the plaintiff has sought to use the doctrine of res ipsa loquitur which, in all jurisdictions, avoids a nonsuit. ${ }^{33}$ For three reasons the plaintiff seeking to employ res ipsa has almost uniformly failed. First, the inference that res ipsa provides is not needed where direct evidence shows the precise cause of the damage or injury and all relevant facts needed to appraise the architect's conduct are known. ${ }^{34}$ Second, where the plaintiff cannot prove the precise cause of damage or injury alleged to be the product of the architect's neghigence he usually cannot satisfy ${ }^{35}$ the fundamental prerequisite ${ }^{36}$ that absent negligence on the part of an architect such damage or injury usually does not occur. Third, the plaintiff

30 Cf. Schillie v. Atchison, T. \& S.F. Ry., 222 F.2d 810, 812-13 (8th Cir. 1955).

31 Graham v. Pennsylvania Co., $139 \mathrm{~Pa} .149,21$ A. 151 (1891).

32 Hommel v. Badger State Inv. Co., 166 Wis. 235, 241, 165 N.W. 20, 22 (1917).

33 See W. Prosser, supra note $11, \S 40$, at 232-34.

34 Day v. National United States Radiator Corp., 241 La. 287, 302, 128 So. $2 d 660,665$ (1961).

${ }^{35}$ Cf. Getty Oil Co. v. Mills, 204 F. Supp. 179, 194 (W.D. Pa. 1962). But see Schreiner v. Miller, 67 Iowa 91, 24 N.W. 738 (1885). It is not altogether clear whether the Schreiner court gave plaintiff the benefit of res ipsa to prove negligence, or whether it implied a warranty that the foundation would in fact be deep enough to prevent the walls from cracking. Probably settlement of the foundation is the one area where res ipsa is readily available to the plaintiff. See C. Cowgral \& B. Small, supra note 6, at 74.

36 See W. Prosser, supra note 11, \& 39, at 218. 
often cannot meet the requirement that the damage be caused by an instrumentality within the defendant's exclusive control ${ }^{37}$ the exclusive control requirement is not satisfied where the client has had possession of the structure for a substantial period of time.$^{38} \mathrm{~A}$ broad interpretation of this requirement would preclude the use of res ipsa whenever the damage occurs after acceptance by the client. However, the reason for the exclusive control requirement is that the inference of negligence provided by res ipsa may not point to any particular person as the tortfeasor. So if negligence on the part of someone is probable, and the plaintiff proves that no one other than the architect could have been negligent, there is no reason to deny the use of res ipsa. ${ }^{30}$

\section{Types of Architect Negligence}

The very complexity of buildings means that negligent formulation of plans and specifications can mauifest itself in inyriad ways. Ideally the completed plans and specifications should do four things: conform with the instructions given the architect and with all client-architect agreements; comply with all applicable laws; not infringe the rights of any third person; and be in accordance with all rules of the architect's science and art. ${ }^{40}$ When reality falls short of the ideal it is often the client who is directly damaged. Because the client and architect typically have a contract, many violations of tort duty can also be alleged to be breaches of contract.

\section{Complying With Instructions and Client-Architect Agreements}

Particular problem areas relating to instructions and agreements are cost of the structure and incomplete instructions. ${ }^{41}$ Two major problems related to cost of the structure are handled as contract matters and can be briefly dealt with. If the client tells the architect that he will spend

37 Id.

${ }^{38}$ Spencer v. Beatty Safway Scaffold Co., 141 Cal. App. 2d 875, 882-83, 297 P.2d 746, 751 (1956) (defendant constructed bleachers).

39 See W. Prosser, supra note $11, \S 39$, at 223-25.

40 Nave v. McGrane, 19 Idaho 111, 121, 113 P. 82, 85 (1910). Fuller discussion of ways in which the architect may be negligent may be found in sources other than this Comment. See generally W. SADLER, stupra note 5, at 157-335; B. TOMSON, IT's THE LAw 217-72 (1960). This Comment only outlines these areas as background for the more unsettled issues that follow.

41 There is no problem in finding the architect liable for neghigence if the client requests plans for a house with three bedrooms and the architect presents plans for a house with two. Similarly, if the architect is clearly told that the plans must be ready by a certain date and he negligently delays, he is liable. See Edwards v. Hall, $293 \mathrm{~Pa} .97,141 \mathrm{~A}$. 638 (1928); Osterling v. Frick, 284 Pa. 397, 131 A. 250 (1925). 
only a certain amount of money on a structure, and the architect prepares plans and specifications for a building which would cost an amount greatly in excess of the set amount, ${ }^{42}$ the architect cannot recover for his services unless the owner accepts the plans. ${ }^{43}$ In such a case an action by the architect asking for compensation for services rendered is in contract, and so is the defense raised by the chent. The architect conditioned his right to compensation on production of plans for a building of a certain cost. ${ }^{44} \mathrm{~A}$ complete failure to discuss cost of the structure is also handled as a contract matter with the cases divided on the issue of whether the chent or the architect has the duty to raise the question of cost in their contract negotiations. ${ }^{45}$

Tort hability involving cost of the structure arises in one of two ways: First, where the architect merely gives an estimate as to how much a building fitting the client's desires will cost, rather than agreeing to stay under a stipulated price; second, when too costly a material is specified.

If it appears that a cost figure is used in the contract merely by way of estimate, rather than as a stipulated maximum, ${ }^{46}$ what are the rights of the parties if the plans and specifications as prepared call for a building above the estimated price? If the architect has fashioned his estimate in a reasonable way, he recovers for his services and the chent cannot recover any damages. ${ }^{47}$ The architect need only figure the cost of materials and labor under current market conditions and give some reasonable consideration to trends in prices. ${ }^{48}$ Reasonably calculated estimates inay be

42 E.g., Rosenthal v. Gauthier, 224 La. 341,69 So. 2 d 367 (1953) ( $\$ 100,000$ agreed upon, $\$ 123,000$ cost); Bruno v. Williams, 76 So. 2d 41 (La. Ct. App. 1954) (\$43,000 agreed upon, $\$ 55,000$ cost); Smith v. Dickey, 74 Tex. 61, 11 S.W. 1049 (1889) (dictum) (\$75,000 agreed upon, $\$ 100,000$ cost). $\$ 70,000$ agreed upon, $\$ 75,000$ cost is close enough to allow the architect to recover. Vaky v. Phelps, 194 S.W. 601 (Tex. Civ. App. 1917).

43 Rosenthal v. Gauthier, 224 La. 341,69 So. 2d 367 (1953); Bruno v. Williams, 76 So. 2d 41 (La. Ct. App. 1954).

44 Wetzel v. Roberts, 296 Mich. 114, 121, 295 N.W. 580, 583 (1941).

40 Compare, e.g., Clark v. Smith, 234 Wis. 138, 290 N.W. 592 (1940) (architect has no duty to inquire about cost), with Cann v. Rector, Wardens \& Vestrymen of Church of the Redeemer, 111 Mo. App. 164, 85 S.W. 994 (1905) (architect does have duty to inquire).

46 The problem of deciding whether a figure listed in a contract is an estimate or a stipulated maximum is a question of contract interpretation that need not intrude into this discussion of tort hability. See generally Spitz v. Brickhouse, 3 IIl. App. 2d 536, 123 N.E.2d 117 (1954) (form contract construed against architect); Schwender v. Schrafft, 246 Mass. 543, 141 N.E. 511 (1923); Smith v. Dickey, 74 Tex. 61, 11 S.W. 1049 (1889); ARCEITECrURAL Practice, supra note 6, bk. III, § 3.01-.07 (AIA members usually inake estimates).

47 See Benenato v. McDougall, 166 Cal. 405, 137 P. 8 (1913); Coombs v. Beede, 89 Me. 187, 36 A. 104 (1896); Capitol Hotel Co. v. Rittenberry, 41 S.W.2d 697, 705 (Tex. Civ. App. 1931).

48 Architectural Practice, supra note 6, bk. III, $\S 3.01$. 
inaccurate because of the many factors that underlie costs-e.g., whether it is a good year for contractors, or whether there are material shortages because of strikes, wars, or shifts in consumer demand. ${ }^{40}$ These factors are obviously outside the control of even the most careful architect.

If plans result in too costly a structure by specifying an expensive material, when architects are using a material of equal quahity and lower cost as a standard practice, then the architect has at least been neghigent, and perhaps even fraudulent, and some form of damages will be assessed..$^{50}$ This assumes, of course, that the client has not requested the more expensive material.

Incomplete instructions pose the second general problem in the relationship between the architect and his client. Although the client knows generally the kind of structure he wants he may not articulate fully the details of his ideas. The "reasonable" architect need not inquire about every detail. But he must, for example, find out several points of information from a client who has only told him that more stories will be added at a later date to a structure the architect is currently planning: the number of stories to be added, their purpose, and the desired means of access from the present structure to the added stories. ${ }^{51}$ Otherwise the chent who is left with a structure totally unsuited for the later additions may recover damages from the architect for neghigent planning. The architect, not the client, can best foresee the problems that may arise from planned future additions.

\section{Complying With Applicable Laws}

Common sense supported by case law $w^{62}$ dictates that an architect who is told of the location of a proposed building and who prepares plans and specifications that are unusable because they do not conform with laws applicable to buildings on that lot should not be able to recover his fee. The client should recover any resulting damages, assuming that he has not directed preparation of the plans and specifications knowing that they will violate the law. As a professional, the architect, not the client, should have to know about building codes and zoning ordinances. ${ }^{63}$ This failure to meet applicable laws may be treated as failing to meet an implied

40 See Benenato v. McDougall, 166 Cal. 405, 137 P. 8 (1913); Coombs v. Beede, 89 Me. 187, 36 A. 104 (1896); Arcertectural Practice, supra note 6, bk. III, § 3.01; W. Parker \& F. Adams, The AIA Standard Contract Forms and the Law 5 (1954).

${ }^{50} \mathrm{Cf}$. Benenato v. McDougall, 166 Cal. 405, 137 P. 8 (1913).

51 Nave v. McGrane, 19 Idaho 111, 119-20, 113 P. 82, 85 (1910).

52 Medoff v. Fisher, $257 \mathrm{~Pa} .126,101$ A. 471 (1917); Bott v. Moser, 175 Va. 11, 7 S.E.2d 217 (1940); Bebb v. Jordan, 111 Wasb. 73, 189 P. 553 (1920).

53 Often inspection of the ordinances would disclose the illegality only to one skilled in building construction. Bebb v. Jordan, 111 Wasl. 73, 189 P. 553 (1920). 
term in the contract, ${ }^{54}$ or as failing to use the due care of a reasonable architect. $^{.5}$

\section{The Rights of Adjoining Landowners}

Cases dealing with architect violation of the rights of adjoining landowners usually involve the problems of lateral support or surface waters. In both areas the architect is liable only if lie fails to take reasonable care to see that his client will not be liable as a landowner to adjoining landowners.

An architect is liable if he fails to take reasonable precautions to make sure that his client's neiglibors will not liave the soil rug pulled out from under their structure. A landowner has an interest in adjoining land for the lateral support of his soil; the architect must respect this interest either because of a common law duty ${ }^{66}$ or a statute. ${ }^{67}$

An architect's plans for grading the client's lot or for placing the structure on that lot will obviously affect the flow of surface water over the client's land and onto his neighbor's. In jurisdictions following the "reasonable user" rule for surface waters a landowner can use his land in a way ordinary to the area even if this causes a deflection of surface water injurious to a neighbor. ${ }^{59}$ In such a jurisdiction the architect is liable only if his plans call for grading the land or for disposing of surface waters in an extraordinary way. For instance, a ditch built to trap all the surface water on the client's land and to convey it to the neighbor's land would be deemed an unreasonable use of the land. ${ }^{80}$ In a jurisdiction following the "civil law rule" the landowner is liable when le disturbs the natural flow of surface waters in a way injurious to his neighbor; ${ }^{62}$ the architect is liable if he fails to use due care to avoid such an injury. ${ }^{63}$

54 Bebb v. Jordan, 111 Wash. 73, 78, 189 P. 553, 555 (1920). If the architect agrees to modify the plans to conform with applicable laws he can recover for his services. See Davis v. Boscov, 72 Cal. App. 323, 237 P. 401 (1925).

${ }_{55}$ See W. Prosser, supra note 11, $\$ 93$, at 638.

56 Cf. S.H. Kress \& Co. v. Reaves, 85 F.2d 915 (4th Cir.), cert. denied, 299 U.S. 616 (1936).

57 Peak v. Richmond Elementary School Dist., 161 Cal. App. 2d 366, 326 P.2d 860 (1958); cf. Green v. Berge, 105 Cal. 52, 38 P. 539 (1894). For a thorough discussion of the architect's hability in the area of lateral support, see W. SADLER, supra note 5, at 281-334.

E8 E.g., United States v. Shapiro, Inc., 101 F. Supp. 27 (D.D.C. 1951), aff'd, 202 F.2d 459 (D.C. Cir. 1953); Enderson v. Kelehen, 226 Minn. 163, 32 N.W.2d 286 (1948).

50 Kinyon \& McClure, Interference With Surface Waters, 24 MinN. L. REv. 891, 904 (1940).

${ }^{60}$ See United States v. Shapiro, Inc., 101 F. Supp. 27 (D.D.C. 1951), aff'd 202 F.2d

459 (D.C. Cir. 1953); Housing Authority v. Ayers, 211 Ga. 728, 88 S.E.2d 368 (1955).

61 Johannsen v. Otto, 225 Iowa 976, 282 N.W. 334 (1938) (adopts civil law rule with modifications).

62 Kinyon \& McClure, supra note 59 , at 893 n.4.

63 The architect is sometimes confronted with sphit authority within a jurisdiction as 


\section{Negligence in Failure to Plan in Accordance with the Rules of the Architect's Science and Art}

Every specification for every component of construction must be prepared with due care. Of course liability for failure to exercise due care will not arise unless damage is caused by the negligence. Hence, proof that the contractor failed to follow the negligently prepared plan or specification relieves the architect of liability because in such a case the architect's negligence is not causally related to the ensuing damage. ${ }^{04}$

Architects miglit fail to use due care in various ways. The architect may inadequately consider the nature of the soil under the building; ${ }^{\text {or }}$ lie may design an inadequate foundation; ${ }^{60}$ he may design a roof too weak to support the weight it will foreseeably have to bear; ${ }^{67}$ he may insulate ${ }^{08}$ or soundproof ${ }^{09}$ the building inadequately. The architect may negligently design a sewer so that waste is carried toward rather than away from the house, ${ }^{70}$ le may design windows too small or too large, ${ }^{71}$ he may fail to put a handrail on a stairway, ${ }^{72}$ or he may specify that nails rather than bolts be used to secure a sundeck. ${ }^{73}$ In each case the question is the same: Did the architect deviate from standard practice, and, if so, did such deviation represent a failure to use due care ${ }^{74}$ In addition the architect may negligently fail to notice a defect in the work of a consultant he lias hired to help prepare the plans and specifications. ${ }^{75}$ The architect would also

to which of the two rules is to be followed. Note, 17 Hastings L.J. 826 (1966). In this situation the architect will probably avoid liability if lie plans in accord with either rule. An architect is not responsible for failing to predict accurately the ultimate decision in the jurisdiction as to which rule will prevail because such a failure would not indicate a lack of due care.

64 Day v. National United States Radiator Corp., 241 La. 287, 310, 128 So. 2d 660, 668 (1961).

O5 Matthews v. Rudy, 4 La. App. 226 (1926) ; cf. S.H. Kress \& Co. v. Reeves, 85 F.2d 915 (4th Cir.), cert. denied, 299 U.S. 616 (1936); Bonadiman-McCain, Inc. v. Snow, 183 Cal. App. 2d 58, 6 Cal. Rptr. 52 (1960).

66 See White v. Pallay, 119 Ore. 97, 247 P. 316 (1926).

67 School Dist. No. 172 v. Josenhans, 88 Wash. 624, 153 P. 326 (1915).

68 Bloomsburg Mills, Inc. v. Sordoni Constr. Co., 401 Pa. 358, 164 A.2d 201 (1960).

69 See Stewart v. Boehme, 53 ㄱll. App. 463 (1893).

70 Cf. Murray v. Jibben, 81 S.D. 359, 135 N.W.2d 227 (1965).

71 Erskine v. Johnson, 23 Neb. 261, 36 N.W. 510 (1888) (dictum).

72 Montijo v. Swift, 219 Cal. App. 2d 351, 33 Cal. Rptr. 133 (1963).

73 Cf. Pieri v. Rosebrook, 128 Cal. App. 2d 250, 275 P.2d 67 (1954).

74 See text accompanying notes 8-23 supra.

75 See Hubert v. Aitken, 19 N.Y. St. Rep. 914, 2 N.Y.S. 711 (C.P. 1888), aff'd on reargument, 5 N.Y.S. 839 (C.P. 1889), aff'd mem., 123 N.Y. 655, 25 N.E. 954 (1890); Scott v. Potomac Ins. Co., 217 Ore. 323, 341 P.2d 1083 (1959). Whether an architect would be liable for failure to detect a consultant's error where a reasonable architect would fail to detect the error because of a lack of technical knowledge about the consultant's specialty is not altogether clear. Id. at 334,341 P.2d at 1088, suggests the architect would be liable in such a situation on an agency theory. See generally Note, 48 CaIIF. L, REv. 151 (1960). 
probably be liable for damage caused by his failure to hire a consultant where a reasonable architect would have done $50 .{ }^{76}$

Negligence in design can be based on negligently incomplete specifcations as well as upon complete but erroneous ones. The plans and specifications must be complete and unambiguous. ${ }^{77}$ For example, specifications are negligently prepared if they are so indefinite that a contractor can bid as if he were going to use first class materials and then build using inferior materials. ${ }^{78}$ If ineasurement of a material is involved, the specification must distinguish between dry and hquid states, or loose or tight packing, where there is any chance of ambiguity. ${ }^{79}$

The architect will typically be hable for each of the deficiencies discussed above even if the client has approved the plans. The client hires an architect to do things that the client either cannot do because of a lack of technical skill, or does not wish to do. If the client does not know the rules of architecture, he lacks the competence to approve the plans in a meaningful way so as to reheve the architect from liability. ${ }^{80}$ If a professional

Such a result seems justified. The architect usually maintains control over his consultants; therefore, the consultants are not independent contractors in their relationship with the architect. White, Professional Liability Insurance, 45 Adr. INST. OF ARCHITECTs ARcHrTECTURE J. 47, 52 (1966). Contra, Note, supra at 156 n.37. The "California Form of Agreement for Consultant Services," sponsored by the California Council of the AIA in 1965 , seeks to make the consultant an independent contractor. In such a case, assuming the contract language represents accurately the real relationship, the architect could not be held liable as principal for the consultant's negligent mistakes. Concern in this area will undoubtedly increase because architects hire consultants frequently. Letters from 25 architects to Jeff Sobel, supra note 19, show that all 25 use consultants on some projects, 21 on at least $50 \%$ of all projects, 11 on at least $90 \%$ of all projects.

76 Cf. Benson v. Dean, 232 N.Y. 52, 58-59, 133 N.E. 125, 127 (1921).

77 Nave v. McGrane, 19 Idaho 111, 117-18, 113 P. 82, 84 (1910); 1 C. McCullougH \& J. McCuLLodGH, supra note 7, at 195 (1946). But see Ressler v. Nielsen, 76 N.W.2d 157 (N.D. 1957) (enough to specify "elevator pit" without specifying dimensions).

78 Nave v. McGrane, 19 Idaho 111, 117-18, 113 P. 82, 84 (1910). Specifications of the quality of material to be used can be a very complex problem. See generally C. Cowant, \& B. SAralI, supra note 6, at 133-34 (3d ed. 1959). If the contract is defimite as to quality and the architect supervises construction as well as planning, then he will be bable if the contractor uses an inferior material and the architect neghigently fails to discover and condemn such use. Skidmore, Owings \& Merrill v. Connecticut Gen. Life Ins. Co., 25 Conn. Supp. 76, 197 A.2d 83 (Super. Ct. 1963).

79 Nave v. McGrane, 19 Idaho 111, 122-23, 113 P. 82, 86 (1910). The problem of ambiguity can arise in the use of words as well as in physcal measurements. A careful architect will discrimmate with precision between the use of "will" (which architects do not deem to be a mandatory form) and "shall be" or "must be" (mandatory) in the specifications. ARchitecrurat Practice, supra note 6 , bk. III, § 5.03 . No case has yet arisen dealing with such a problem.

80 E.g., Nave v. McGrane, 19 Idaho 111, 121, 113 P. 82, 85 (1910); Bloomsburg Mills, Inc. v. Sordoni Constr. Co., 401 Pa. 358, 164 A.2d 201 (1960) ; cf. Looker v. Gulf Coast Fair, 203 Ala. 42, 81 So. 832 (1919); Louisiana Molasses Co. v. Le Sassier, 52 La. Ann. 2070, 28 So. 217 (1900); Simpson Bros. v. Merrimac Chem. Co., 248 Mass. 346, 142 N.E. 922 (1924). 
builder hires an architect-or even if an architect hires another architect - to design his house because he does not wish to plan it himself, the client's approval of the plans should still usually not relieve the architect of hability. However, contributory negligence would seem to bar recovery where the knowledgeable client becomes aware of a defect and allows building to proceed anyway, or where he should notice a defect because he either casually inspects the plans and the defect is obvious or he carefully inspects and thereby should become aware of a defect. ${ }^{81}$

\section{To Whom Is the Negligent Architect Liable}

The architect is of course liable to his client for negligently prepared plans and specifications. ${ }^{82}$ The contractor hired by the client to build the structure, althougl not in privity with the architect, may recover from the architect any extra costs resulting from the architect's negligent plans. ${ }^{83}$ In addition, all jurisdictions deciding the issue have held that, regardless of privity, all persons lawfully on the premises may recover from the architect for injuries to person or property due to his negligence in preparing plans and specifications if the injuries occur before the structure is completed and accepted by his client. ${ }^{84}$

The greatest activity in recent years is in the area of liability to parties not in privity with the architect who are injured or suffer damage due to the architect's negligence after acceptance of the architect's work by the client. For one hundred years after Winterbottom v. Wright ${ }^{85}$ was applied to architects in $1849,{ }^{86}$ negligent architects had no responsibility to third parties injured after the client accepted the structure built according to the architect's plans and specifications. Courts justified different treatment of architect's liability before and after acceptance of his work because the architect could not remedy defects due to his negligence once he gave up control of the premises. ${ }^{87}$ Although there was no logical distinction between producers of chattels and independent contractors like the architect who designed and built structures, the doctrine of MacPherson $v$.

81 See Looker v. Gulf Coast Fair, 203 Ala. 42, 81 So. 832 (1919) ; cf. W. SADLER, supra note 5 , at 203.

82 E.g., Bloomsburg Mills, Inc. v. Sordoni Constr. Co., 401 Pa. 358, 164 A.2d 201 (1960).

83 Cf. United States v. Rogers \& Rogers, 161 F. Supp. 132 (S.D. Cal. 1958).

84 Pötter v. Gilbert, 130 App. Div. 632, 115 N.Y.S. 425 (dictum), afj'd mem., 196 N.Y. 576, 90 N.E. 1165 (1909); W. Prosser, supra note 11, § 99, at 693.

8510 M. \& W. 109, 152 Eng. Rep. 402 (Ex. 1842) (no recovery absent privity from one contracting to keep nuailcoach in repair). See generally W. ProsSER, supra note $11, \S 96$, at 658-60.

86 See Mayor \& C. of Albany v. Cunliff, 2 N.Y. 165 (1849).

87 See Gouldin, Liability of Architects and Contractors to Third Persons: Inman v. Binghampton Housing Authority Revisited, 33 Irs. Coussex J. 361, 363 (1966). 
Buick Motor Company ${ }^{88}$ was not quickly applied to independent contractors in the construction industry in general and to architects in particular. Few cases between 1840 and 1945 involving architects dealt with this issue, but courts did not distinguisli architects from other independent contractors. ${ }^{89}$ The rule of no liability without privity after the client accepted the independent contractor's work was perpetually repeated and almost as frequently limited by one of many exceptions. ${ }^{90}$ Exceptions were made for work turned over to the client which was so defective as to be imminently dangerous to third persons, ${ }^{91}$ for "willful negligence," situations where an invitation by the architect to the third person to use the structure could be implied, ${ }^{93}$ or for nuisance..$^{94}$ Only after 1945 was MacPherson applied at all to those planning or constructing buildings, ${ }^{95}$ and in the mid-1950's the majority of jurisdictions ${ }^{96}$ still would not extend MacPherson to an area where it obviously should apply. ${ }^{97}$ In 1956 the abandonment of the privity requirenient could only be called a "modern tendency."

Less than ten years later it could fairly be said that the MacPherson doctrine as applied to architects had been accepted in most states. ${ }^{99}$ In Montijo v. Sreift, ${ }^{100}$ a good example of judicial rejection of the privity

88217 N.Y. 382, 111 N.E. 1050 (1916) (automobile manufacturer liable absent privity for making car with defective wheel).

${ }^{89}$ See, e.g., Geare v. Sturgis, 14 F.2d 256 (D.C. Cir. 1926).

80 The exceptions started appearing as early as 1882 . See Devlin v. Smith. 89 N.X. 470 (1882).

91 Ford v. Sturgis, 14 F.2d 253 (D.C. Cir. 1926) (stating exception but not applying it); Johnston v. Long, 56 Cal. App. 2d 834, 133 P.2d 409 (1943); Berg v. Otis Elevator Co., 64 Utah 518, 231 P. 832 (1924) (stating exception but not applying it).

92 Murply v. Barlow Realty Co., 206 Minn. 527, 289 N.W. 563 (1939) (contractor);

Greenwood v. Lyles \& Buckner Inc., 329 P.2d 1063 (Okla. 1958) (contractor).

93 Colbert v. Holland Furnace Co., 333 ㄱll. 78, 164 N.E. 162 (1928).

94 Kendrick v. Mason, 234 La. 217, 99 So. 2d 108 (1958) (contractor).

95 Bearman, Caveat Emptor in Sales of Realty-Recent Assaults Upon the Rule, 14 VAND. L. REv. 541, 567 (1961).

96 See Knorr, Building up to an Awful Let-Down, 6 Ciev.-Mar. L. Rev. 514, 520 (1957).

07 See 2 F. Harper \& F. JaAres, The Law of Torts § 18.5, at 1043 (1956). Possible distinctions between manufacturers and those who plan or construct buildings liave been suggested. "The manufacturer makes standard goods and develops standard processes. Defects are larder to find in the contractor's special jobs. Again, the owner usually gives more thorough inspection to a building or structure than a vendee gives to a chattel. And a longer time may elapse between construction and injury in the contractor's case with the consequently greater opportunity for intervening factors to play a part. These considerations, however, go to the question of negligence and should be treated simply as problems of proof in individual cases." Id.

98 Id.

99 W. PROSSER, supra note 11, § 99, at 695.

100219 Cal. App. 2d 351, 33 Cal. Rptr. 133 (1963). 
doctrine, an architect failed to extend a handrail all the way to the bottom step in a bus station and a patron in the terminal fell and injured herself. The court held that:

An architect who plans ... construction work . . . is under a duty to exercise ordinary care . . . for the protection of any person who foreseeably and with reasonable certainty may be injured by his failure to do so, even though such injury may occur after his work has been accepted by the person engaging his services. ${ }^{101}$

Two primary differences exist today among jurisdictions which have formally abandoned the requirement of privity after acceptance by the chent. One difference involves the latent defect requirement, and the other involves the types of damages that may be recovered for an architect's neghigence without contractual privity.

Some jurisdictions have qualified their rejection of the privity rule by insisting that a "latent" defect be alleged in order to state a cause of action agamst the architect. ${ }^{102}$ This insistence has been consistently and justifiably attacked by legal writers ${ }^{103}$ and by at least one court. ${ }^{104}$ An architect is neghigent if, not following standard practices, he has created an unrea-

101219 Cal. App. 2d at 353, 33 Cal. Rptr. at 134-35. Accord, Inman v. Binghampton Housing Authority, 3 N.Y.2d 137, 143 N.E.2d 895, 164 N.Y.S.2d 699 (1957); cf. Hanna v. Fletcher, 231 F.2d 469 (D.C. Cir. 1956); Moran v. Pittsburg-Des Moines Steel Co., 166 F.2d 908 (3d Cir. 1948); Pastorelli v. Associated Eng'rs, 176 F. Supp. 159 (D.R.I. 1959); Rogers v. Meyers \& Smith, Inc., 57 Ill. App. 2d 200, 206 N.E.2d 845 (1965); Russell v. Arthur Whitcoinb, Inc., 100 N.H. 171, 121 A.2d 781 (1956); Schipper v. Levitt \& Sons, 44 N.J. 70, 207 A.2d 314 (1965) ; Council v. Dickerson's, Inc., 233 N.C. 472, 64 S.E.2d 551 (1951); American Reciprocal Insurers v. Bessonette, 241 Ore. 500, 405 P.2d 529 (1965); DeTillo v. Carlyn Constr., Inc., 416 Pa. 469, 206 A.2d 376 (1965); Restatenrent (Second) of Torts $\S 385$ (1965). For discussion of California in particular, see generally Note, 15 HAStings L.J. 579 (1964). Even the most recent decisions of some jurisdictions still cling to the old general rule of nonliability absent privity limited by exceptions. E.g., Hartwich v. Crotty, 131 Colo. 69, 279 P.2d 413 (1955); Del Gaudio v. Ingerson, 142 Conn. 564, 115 A.2d 665 (1955); Gruhalla v. George Moeller Constr. Co., 391 S.W.2d 585 (Mo. Ct. App. 1965); Wilson v. North Cent. Gas Co., 163 Neb. 664, 80 N.W.2d 685 (1957); City of Richmond v. Branch, 205 Va. 424, 137 S.E.2d 882 (1964).

102 Inman v. Binghampton Housing Authority, 3 N.Y.2d 137, 145, 143 N.E.2d 895, 899, 164 N.Y.S.2d 699, 704 (1957). Although Inman is the most promment decision, cases in other states also require a plaintiff not in privity of contract with the architect to allege a latent defect in order to state a cause of action. Cf. Stevens v. Allis-Chalmers Mfg. Co., 151 Kan. 638, 100 P.2d 723 (1940); Tyson v. Long Mfg. Co., 249 N.C. 557, 107 S.E.2d 170 (1959); Fisher v. Simon, 15 Wis. 2d 207, 112 N.W.2d 705 (1961). Apparently California is among the jurisdictions not requiring an allegation of a latent defect. 2 SaN DIEgo $L$. REV. 123, 125 (1965).

1032 F. HARPER \& F. JAMES, supra note 97, § 28.5, at 1544 (1956); Bell, supra note 3; Noel, Manufacturer's Negligence of Design or Directions for Use of a Product, 71 Yar. L.J. 816, 836-41 (1962); Thornton \& McNiece, Torts and Workmen's Compensation, 32 N.Y.U.L. REv. 1465,1476 (1957).

104 Schipper v. Levitt \& Sons., 44 N.J. 70, 84, 207 A.2d 314, 322 (1965). See also Messina v. Clark Equip. Co., 263 F.2d 291, 293 (2d Cir. 1959) (dissenting opinion). 
sonable risk through lack of due care. The obviousness of a defective condition is simply one factor to be considered in deciding whether the danger created is unreasonable; even where danger is manifest the defect may still be unreasonably hazardous. As in most negligence cases, the reasonableness of this risk should be for the jury ${ }^{105}$ with the aid of expert testimony. However, the latent defect requirement blocks plaintiffs from even getting to court, let alone to the jury.

The latent defect requirement might be understandable if viewed as a heightened concern by the courts over the issues of contributory negligence or proximate cause. It might be argued that the plaintiff who suffers injury due to a patent defect is contributorily negligent. However, there is no reason to treat the issue of contributory negligence in architect cases differently than in other cases where it is left for the jury. ${ }^{108}$ The latent defect requirement can be viewed as involving proximate cause if the person owning the building fails to correct the defect and a third person is injured; the owner's negligence has superseded the architect's negligence as a proximate cause of the injury. ${ }^{107}$ As in other negligence cases, however, courts should leave proximate cause to the jury ${ }^{108}$ instead of using possible lack of proximate cause to keep the plaintiff out of court altogether.

The language of the cases, however, does not indicate that heightened concern about proximate cause ${ }^{109}$ or contributory negligence motivated the latent defect requirement. It seems probable that courts, reluctant to let juries rule on the sometimes complex designs of architects in cases involving great sums of money, ${ }^{110}$ may use devices such as the latent defect requirement to keep the case out of court altogether. This fear is unwarranted if proper expert evidence ${ }^{111}$ and jury instructions are given. Deserving plaintiffs should not be denied their day in court in an attempt

$105 \mathrm{~W}$. Prosser, supra note $11, \S 52$, at 330 .

106 Id. § 64, at 430.

107 Cf. Campbell v. Barnett, 351 F.2d 342 (10th Cir. 1965). The preferable analysis is that if it is foreseeable that the second person would not remedy the defect then the architect is still liable. See Restatearent (SeCond) of ToRTs $\$ 447$ (1965).

108 See W. Prosser, silpra note 11, § 52, at 330.

100 Cases imposing the latent defect requirement do not explain the requirement in terms of proximate cause. The proximate cause explanation is suggested by language from earlier cases which required privity of contract in order to sustain an action against the architect after acceptance of his work. The courts noted that once the architect's control over the premises was ended, only the occupier of the land could remedy the situation, and therefore the architect's neghigence was not the proximate cause of the damage. See Ford v. Sturgis, 14 F.2d 253 (D.C. Cir. 1926); Berg v. Otis Elevator Co., 64 Utah 518, 231 P. 832 (1924).

$110 \mathrm{Cf}$. Noel, supra note 103, at 816 .

111 Seg text accompanying notẹs 24-32 supra. 
to prevent a few undeserving plaintiffs from recovering against negligent architects.

Even if the latent defect requirement is retained in the future, the courts should show greater sensitivity to two necessary distinctions. First, if the rule is motivated by heightened concern about contributory negligence or proximate cause, the requirement must surely be for an allegation of a latent danger, not a latent defect. Often a defect may be clearly visible and yet the danger that it creates may be latent. The defect in a porch which lacks a railing ${ }^{112}$ is patent in the sense that the physical conditions that create the dangerous situation are visible to anyone who looks at the porch. But the danger posed by this missing railing may very well be latent, and the latency of the danger, rather than the defect, is relevant when deciding if the plaintiff was contributorily negligent or if the architect's neghigence was superseded. Allegation by the plaintiff of a latent danger, not a latent defect, should therefore be sufficient. ${ }^{118}$

A second desirable distinction is between a danger latent to a reasonable adult with all his senses unimpaired, and a danger latent to the particular person to whom the reason for the requirement relates. If the reason for the rule involves contributory negligence, then the danger should be latent to the particular plaintiff. ${ }^{114}$ The danger from the porch mentioned above might be clearly obvious to an adult but latent to an infant. ${ }^{115}$ If the rule is based on contributory negligence, then in a suit involving an injured infant the question should be whether the danger was latent to him. Similarly, a latent danger rule based on a concern about proximate cause should ask whether the danger was latent to the person owning the structure who failed to correct the defect. If the danger was not patent to that person, then he was not negligent in failing to correct the defect and therefore his negligence cannot be said to have superseded that of the architect. Of course if the requirement is imposed merely as a convenient

112 This example is taken from Inman v. Binghampton Housing Authority, 3 N.Y.2d 137, 143 N.E.2d 895,164 N.Y.S. $2 d 699$ (1957). The court did not show any real sensitivity to the distinction dismissing it with a one-sentence analysis. See id. at 146, 143 N.E.2d at 900,164 N.Y.S.2d at 705.

113 See Thornton \& McNiece, stipra note 103, at 1476; of. Schipper v. Levitt \& Sons, 44 N.J. 70, 84, 207 A.2d 314, 322 (1965).

114 To say the danger must be latent to the particular plaintiff assumes that the characteristic which distinguishes him from the reasonable adult with all his senses unimpaired is one like blindness, deafness, or youth which the law usually takes into account in applying the reasonable man standard to the plaintiff. See W. ProsSER, suppra note 11, $\$ 32$, at 155 , $157-60$.

115 See Bell, supra note 3, at 715. The Inman court in dealing with these facts was apparently unaware of the distinction but at least one lower court in New York has recognized it. See Eilenberg v. O. \& M. Storm Window Co., 17 Misc. 2d 799, 800, 187 N.Y.S.2d 922, 924 (Sup. Ct. 1959). The Eilenberg court gave plaintiff leave to amend the complaint so as to allege a defect latent to the "infant plaintiff." Id. 
method of limiting architect liability, neither of these distinctions, which tend to enlarge liability, need be made.

States rejecting the privity doctrine for some types of damages differ as to what types of damages still require privity for recovery. All states that reject the privity doctrine for some types of damages do so for personal injuries. ${ }^{116}$ Beyond this, because the rejection of the privity requirement is so recent, few cases dealing with independent contractors in general and architects in particular have defined the boundaries of this rejection. Apparently some jurisdictions follow the rule that if the architect's negligence made personal injury probable, the fact that by chance the injury was only to property will not bar recovery. ${ }^{117}$ Other courts allow recovery even though the only risk created by the architect's neghigence was damage to property. ${ }^{118}$ Apparently no cases have yet decided whether recovery will be allowed for property damage to the defectively planned part of the structure itself. Because courts now tend to apply the same negligence rules to suppliers of chattels and to independent contractors in the building industry, they probably will follow decisions holding suppliers liable for defects in the product itself ${ }^{119}$ and hold architects liable for damage to the defective part of the structure. ${ }^{120}$ At least one court held the architect liable for intangible economic loss rather than property damage. In that case, the architect's neghigence cost the contractor money for delays; the court held that the contractor could recover absent privity. ${ }^{121}$ Although this type of loss is perfectly

116 See, e.g., Montijo v. Swift, 219 Cal. App. 2d 351, 33 Cal. Rptr. 133 (1963); Inman v. Binghampton Housing Authority, 3 N.Y.2d 137, 143 N.E.2d 895, 164 N.Y.S.2d 699 (1957) (dictum).

${ }_{117}$ Cf. Kuhr Bros. v. Spahos, 89 Ga. Ct. App. 885, 81 S.E.2d 491 (1954) ; C.D. Herme, Inc. v. R.C. Tway Co., 294 S.W.2d 534 (Ky. Ct. App. 1956).

118 Cf. Stewart v. Cox, 55 Cal. 2d 857, 362 P.2d 345, 13 Cal. Rptr. 521 (1961); Marine Ins. Co. v. Strecker, 234 La. 522, 100 So. 2d 493 (1958). This accords with the majority of the decisions in the area of manufacturers liability. See W. PROSSER, sutpra note 1I, § 96, at 663 .

110 E.g., Fentress v. Van Etta Motors, 157 Cal. App. 2d 863, 323 P.2d 227 (1958); Quackenbush v. Ford Motor Co., 167 App. Div. 433, 153 N.Y.S. 131 (1915).

120 Cf. Fisher v. Simon, 15 Wis. 2d 207, 112 N.W.2d 705 (1961) (builder-vendor treated as independent contractor). The requirement sometimes found in the automobile damage cases, e.g., Fentress v. Van Etta Motors, 157 Cal. App. 863, 323 P.2d 227 (1958); Quackenbush v. Ford Motor Co., 167 App. Div. 433, 153 N.Y.S. 131 (1915), that an accident or collision caused by the defect and resulting in the destruction of the defective item must occur in order for recovery would not be appropriate in architect cases. In architect cases injuries to the defective part of the structure itself will rarely be occasioned by "accidents" or "collisions."

121 Cf. United States v. Rogers \& Rogers, 161 F. Supp. 132 (S.D. Cal. 1958). The negligence here was in supervision (the court called it negligent misrepresentation). The court broadly stated that recovery was allowed even when the damage was only to an economic interest. In this area no different principle of law should obtain if the gravamen of the complaint is for negligent planning. 
foreseeable, and even though it may be more injurious than damage to tangible property, most courts will probably follow the majority rule with regard to suppliers of chattels ${ }^{122}$ and deny recovery ${ }^{123}$ for economic loss, finding no reasonable distinction between suppliers of chattels and professionals like the architect.

\section{E. Duration of the Architect's Liability and the Statute of Limitations}

Courts hesitated to make architects liable to third persons long after abandoning a privity requirement for producers of products because of the great potential duration of architects liability. ${ }^{124}$ The statute of limitations should not begin to run against the plaintiff until the architect's negligence causes damage. ${ }^{125}$ Until then no cause of action exists because damage is an element of a negligence cause of action. ${ }^{126}$ Arguments for starting the statute of limitations running at the time of the architect's negligent act ${ }^{127}$ or when the client accepts the structure, ${ }^{128}$ rather than when damage occurs as with products hability, are unpersuasive. Because damage resulting from a defect in architectural plans may not occur for many years, ${ }^{129}$ whereas damage caused by a defective product normally occurs fairly soon, a causal connection between the architect's negligence and the damage many years later may be improbable. But as some cases have emphasized, "The mere passage of time [does] not break the chain of causation . ..."130 Lapse of time

122 E.g. Trans World Airlines, Inc. v. Curtiss-Wright Corp., 1 Misc. 2d 477, 148 N.Y.S.2d 284 (Sup. Ct. 1955).

123 Whether or not purely economic interests deserve protection in tort is an issue far broader than the scope of this Comment. See generally W. Prosser, stipra note $11, \S 123$.

124 See F. HARPER \& F. JAMES, stcpra note 97, at 1043.

125 Cf. Hanna v. Fletcher, 231 F.2d 469 (D.C. Cir. 1956). But see Wellston Co. v. Sam N. Hodges, Jr. \& Co., 114 Ga. App. 424, 151 S.E.2d 481 (1966); Wills v. Black \& West, Architects, 344 P.2d 581 (Okla. 1959).

126 See W. Prosser, supra note 11, § 30, at 147.

127 Wellston Co, v. Sam N. Hodges, Jr. \& Co., 114 Ga. App. 424, 151 S.E.2d 481 (1966). Wellston held that the statute started running against the plaintiff from the time the roof was neghgently planned and constructed even though plaintiff had no knowledge of the neghigence until the roof collapsed four years after acceptance of the structure. This rule is too hard on the plaintiff because it demes him recovery for failure to discover a defect which was probably impossible for him to discover.

128 Wills v. Black \& West, Architects, 344 P.2d 581 (Okla. 1959). Wills held that acceptance of the structure started the statute of limitations running at least in part because the joists that caused a leak in the roof after five years could be seen from the back of the house. To the extent this decision rehes on the visible joists it is erroneous. The joists were visible, but their defectiveness was not. Perhaps the decision can be justified in that a small leak developed in the roof shortly after it was finished. The statute should have begun to run when the injury occurred.

120 E.g., Hale v. Depaoh, 33 Cal. 2d 228, 201 P.2d 1 (1948) (18 years).

130 Foley v. Pittsburg-Des Moines Co., 363 Pa. 1, 36, 68 A.2d 517, 534 (1949) (contractor-designer of hquified gas tank.) 
should not deny plaintiffs the chance to prove that a causal connection does exist. ${ }^{131}$ Policies behind the statute of limitations, like "peace" for the defendant and the difficulty in obtaining reliable witnesses and proof after the passage of time, might justify starting the statute running when the client accepts the structure. However, the plaintiff cannot sue before lie has a cause of action including damage. Moreover, the burden of proof is on the plaintiff, and if he fails to bring forth sufficient evidence because he is unable to obtain proof and witnesses, the defendant wins whatever the statute of limitations. If "fictitious" evidence is employed in a rare case, it is better to rely on a jury to ascertain that fact than to bar all plaintiffs with legitimate evidence.

\section{II}

\section{STRICT LIABILITY}

Courts have expanded the class of plaintiffs who may recover for injury due to the architect's negligence. ${ }^{132}$ However, holding the architect liable for neghigence is not sufficient. An architect may design a roof in accordance with standard practice and with sucli care that any jury would deny recovery for injuries caused by its collapse. Yet the roof is designed incorrectly because of an honest error in judgment or because of a slight miscalculation that even a reasonable architect miglit make. The roof falls, injures both the architect's client and a visitor in the client's home, and seriously damages the house. Under present architect tort law the architect is not liable. The client and lis visitor, who perhaps can ill afford to bear their losses, must do so even though they were caused by the architect's mistake. Architects should be held strictly liable for such injuries caused by nonnegligent errors inevitable in the course of their business. ${ }^{133}$ Logic alone does not lead to that conclusion. The con-

131 See 2 F. HARPER \& F. JAMrEs, supre note 97, § 18.5, at 1042.

132 See text accompanying notes 82-101 supra.

133 To argue that those who provide services should be strictly liable one must assume that one of the judgments implicit in strict liability for suppliers of chattels is correct: "fault" as it is used in traditional tort theory-viz., to signify a departure from the conduct of a reasonable man-is not so vital a prerequisite to liability that it nay not be sacrificed in order to obtain the benefits of spreading inevitable loss to a wide number of individuals. The literature in favor of liability "without fault" is abundant. E.g., Ehrenzweig, Negligence Without Fault, 54 CALIF. L. REv. 1422 (1966); McNiece \& Thornton, Is the Law of Negligence Obsolete?, 26 Sr. JoHN's L. REv. 255 (1952). Some, lowever, question liability without fault. See Blun \& Kalven, Public Law Perspectives on a Private Law ProblemAuto Compensation Plans, 31 CrI. L. Rev. 641, 721-23 (1964).

It is assumed that strict liability will be imposed by the courts as it has been in the area of products liability rather than by a more radical approach. Perhaps a later day will find the courts displaced as implementers of strict liability in favor of legislatively imposed compulsory insurance, see Marx, Compensation Insurance for Automobile Accident Victims: The Case for Compulsory Automobile Compensation Insurance, 15 Онто ST. L.J. 134 (1954), or widespread social insurance compensating for all losses, see Blum \& Kalven, 
clusion rests on a value judgment: It is better that each of five hundred people bear one five-hundredth of the loss than that one person bear all the loss. This "spreading effect" would result from the architect's purchase of insurance and passage of its cost to his clients. This section will discuss the damage for which architects should be strictly liable, existing imadequacies in compensating damage caused by the architect's nonnegligent errors and, finally, objections to imposition of strict liability.

\section{A. Damages for Which the Architect Should be Strictly Liable}

The architect should be liable for all injury or loss resulting from either defects in the structure caused by his plans or work carried on in compliance with the plans which produce an unreasonable danger of injury to person or property or seriously reduce the value of the structure to a reasonable man. This differs from the negligence standard in that it looks to the seriousness of the damage which might occur rather than to the reasonableness of the architect's method of producing it. Recovery should be allowed where the defect poses an unreasonable danger even though the architect was not negligent. ${ }^{134}$

This proposed formula for strict liability is designed to cover those areas where the need to spread loss is greatest. Severe personal injury will not go uncompensated merely because the architect created an unreasonable danger in a nonnegligent manner. ${ }^{135}$ Severe property damage caused by erroneous plans, whether negligently created or not, will be compensated. Finally, those defects that seriously lessen the value of

supra at 721-23. The precise details of how to shift the loss are less important for purposes of this Comment than whether or not the loss should be shifted through the more traditional approach.

134 For example, a carefully designed roof might fall because the architect did not discover, even after making every reasonable soil test, that the foundation would settle and cause the collapse of the roof. The roof would create an "unreasonable" risk because, although the probability that the roof would collapse might have been low, if it collapsed, the probability of serious harm would be so great as to present an unreasonable risk.

135 The formula used in the developing field of warranties in house construction which imposes liability regardless of negligence if the finished structure is not "habitable," e.g., Weck v. A:M Sunrise Constr. Co., 36 Ill. App. 2d 383, 184 N.E.2d 728 (1962); Hoye v. Century Builders, Inc., 52 Wash. 2d 830, 329 P.2d 474 (1958), or "reasonably fit for habitation," e.g., Vanderschrier v. Aaron, 103 Ohio App. 340, 140 N.E.2d 819 (1957); Jones v. Gatewood, 381 P.2d 158 (Okla. 1963), might be suggested as an alternative to the one proposed in this Comment. This formula should be rejected because it fails to place enough focus on personal injuries. One could define "habitable" in such a way that a house which produces personal injuries is not habitable, but this would pervert the common meaning of the word. A house might be perfectly satisfactory and comfortable for years-habitable in the fullest sense of the word. Then one day a piece of stucco falls and injures someone. It stretches the meaning of the word to say the house has now become "uninhabitable." In addition, given the counmon ineaning of the word, the formula does not seem to cover defects against which the law should protect (for example, one cracked wall in an interior bedroom), but which are not so serious as to make the house uninhabitable. 
the structure, even though they do not pose unreasonable danger to person or other property, ${ }^{136}$ will be paid for by the architect. ${ }^{137}$ Only those defects in the structure which seriously lessen its value are included; suits based on strict hability for minor defects which would clog the courts are excluded because there is little reason to worry about spreading the burden of such defects to many people. ${ }^{138}$ The chient could still recover from a neghigent architect for a small defect. This part of the formula would also exclude recovery for exotic "defects"139 arising from the peculiarities of a particular client because it imposes a "reasonable man standard" to judge the seriousness of the defect.

The failure to plan in accordance with the rules of the architect's science and art, discussed above, ${ }^{140}$ will of course be the major area of architect strict liability. It remains to apply this formula to the other types of architect negligence considered in Part I of this Comment. The formula would not apply strict hability to estimates of price. ${ }^{141}$ Since chent and architect are both fully aware that nothing definite is being said about cost, there seems little reason to worry about compensating a chent who must pay more than lie wanted to. Moreover, in many cases

$136 \mathrm{~A}$ foundation that gradually sinks or a cracked wall in one room are examples of such defects.

137 Cases on products liability split on the question whether strict liability, under the test that the defect makes the product "unreasonably dangerous," encompasses defects which only reduce the value of the article. Compare Santor v. A. \& M. Karagheusian, Inc., 44 N.J. 52, 207 A.2d 305 (1965), wit/2 A.JP. Contracting Corp. v. Brooklyn Builders Supply Co., 283 N.Y. 692 (1940).

Whether or not strict liability as to products should include reduced value of the article, strict liability as to architects should include reduced value in the structure. The loss from a defect in the structure can be much greater than most losses from a defect in a product. E.g., Bloomburg Mills, Inc. v. Sordoni Constr. Co., 401 Pa. 358, 164 A.2d 201 (1960) $(\$ 18,645)$. In addition, arguments against imposing strict liability on manufacturers for such defects do not apply to architects: concern about nuisance suits against out-of-state manufacturers, see Comment, Manufacturer's Responsibility for Defective Products: Continuing Controversy Over The Law To Be Applied, 54 CaIIF. L. Rev. 1681, 1712-13 (1966), or the availability of the Uniform Commercial Code as protection, $i d$. at 1694-1707, are not relevant. Allowing suits based on strict liability in tort against architects for "serious defects" seems fully warranted.

138 No court imposing strict liability for products requires "perfection" from a manufacturer. See, e.g., Jakubowski v. Minnesota Mining \& Mfg., 42 N.J. 177, 185, 199 A.2d 826, 831 (1964). See James, The Untoward Effects of Cigarettes and Drugs: Some Reflections on Enterprise Liability, 54 CAIIF. L. REv. 1550-51 (1966). The same may be said about warranties implied in the sale of homes. Schipper v. Levitt \& Sons, 44 N.J. 70, 92, 207 A.2d 314, 326 (1965).

139 For instance, solar heat not utilized to optimum degree in planning structures, see Coast to Coast, Luminaire to Louver, 45 Ax. INST. OF ARCHIECTs J. 66 (1966), or colors not employed so as to maximize their psychological effects, see DanBY, Gramarar of ArcHITECTURAI DEsign 84-85 (1963).

140 See text accompanying notes 64-79 supra.

141 See text accompanying notes 46-49 supra. 
the client paying more than he planned will also have a more valuable building than he expected. If instructions are incomplete ${ }^{142}$ because the architect, although making all reasonable inquiries, has failed to discover the unverbahized and perhaps half-formed desires of his client, the value of the structure to a reasonable man would probably not be seriously reduced and it seems fair to deny recovery. The failure to comply with applicable laws ${ }^{143}$ is usually handled adequately by existing tort law. In the rare case where an architect reasonably fails to discover an applicable statute, or where the building does not comply with a statute although the architect took reasonable steps to try to make it comply, lie should be strictly liable if he fails under the terms of the strict liability standard proposed. If the architect's work results in his client violating adjoining landowner's rights ${ }^{144}$ and the work carried out in accordance with the architect's plans involves unreasonable danger to the person or property of the adjoining landowner, the architect would be liable under the proposed formula.

The client or third person should not have to bear all the loss when the architect caused it and can best spread its effects. This formula would prove no more difficult to use than any other verbal rule that requires case by case development to provide more concrete meaning. Of course, under this proposed test the plaintiff would still have to prove that the defect was caused by the architect's plans or specifications and not because of a contractor error independent of them. The liability imposed would clearly be in tort, ${ }^{145}$ not contract, to avoid any of the problems of sales law ${ }^{146}$ that can arise if the foundation for hability is ambiguous. ${ }^{147}$ In other words, the hability imposed would stem from the force of the law, not the mutual contractual intent of the parties. ${ }^{148}$

142 See text accompanying note 51 supra.

143 See text accompanying notes $52-53$ supra.

144 See text accompanying notes 56-63 supra.

145 Cf. Greenman v. Yuba Power Prods., Inc., 59 Cal. 2d 57, 377 P.2d 897, 27 Cal. Rptr. 697 (1963); Santor v. A. \& M. Karagheusian, Inc., 44 N.J. 52, 207 A.2d 305 (1965); Cowan, Some Policy Bases of Products Liability, 17 Stan. L. Rev. 1077, 1089 (1965).

146 "Sales law" is broadly used here to cover contract warranties for either manufactured products or structures.

147 For instance, a lack of privity will be no bar to recovery for strict liability in tort. Some courts lave held that privity is a requirement for recovery on a warranty in the field of products liability. Cf. Strother v. Villere Coal Co., 15 So. 2d 383 (La. Ct. App. 1943). Even for contract warranties the privity requirement is being eased. Comment, The Contractural Aspect of Consumer Protection: Recent Developments in the Law of Sales Warranties, 65 MICE. L. REv. 1430, 1442-52 (1966). Other problems inight arise with disclaimers and the giving of notice of the breach of warranty if the basis of liability is ambiguous. See W. Prosser, supra note 11, § 97, at 679-81.

148 Cf. Henningsen v. Bloomfield Motors, Inc., 32 N.J. 358, 404, 161 A.2d 69, 95 (1960); Jacob E. Decker \& Sons v. Capps, 139 Tex. 609, 617, 164 S.W.2d 828, 831-32 (1942); 2 F. HARPER \& F. JAMEs, supra note 97 , \& 28.16 , at 1571. 


\section{B. Inadequacies of Present System in Dealing with Architect's Nonnegligent Mistakes}

\section{Strict Liability Today for Architects}

Almost without exception the architect who is not negligent has escaped liability for injury caused by his plans. ${ }^{149}$ Case after case has held that in the absence of an express warranty ${ }^{150}$ the architect is not a guarantor of the plans and specifications he prepares. ${ }^{151}$ Language of a few cases in the last fifty years suggests that the architect does warrant that his plans, if followed, will result in a nondefective structure. However, these cases are poor precedents; in some of them strict liability need not have been imposed because the defendant-architect was clearly negligent, and in others the courts imposed strict liability through misinterpretations of earlier cases. In Trunk \& Gordon v. Clark $k^{152}$ the architects breached a duty to produce a building without marked defects. It is clear that liability for negligence would have led to the same result; for instance, one of the alleged defects was that the private boxes in the opera house had no view of the stage. ${ }^{153}$

The case inost frequently cited $d^{154}$ as proof that architects have been held strictly liable illustrates little but confusion. The court in Hill $v$. Polar Pantries ${ }^{155}$ imposed a warranty on a designer on the theory that if a party furnishes plans and specifications for use by a contractor he warrants their sufficiency. ${ }^{150}$ It reaclied this conclusion by misinterpret-

149 See notes 8-13 supra and accompanying text.

150 Architects sometimes expressly warrant the sufficiency of their plans. Lake v. McElfatrick, 139 N.Y. 349, 34 N.E. 922 (1893); Niver v. Nash, 7 Wash. 558, 35 P. 380 (1893); cf. Smallwood v. Pettit-Galloway Co., 187 Ark. 379, 59 S.W.2d 1031 (1933); City of McPherson v. Stucker, 122 Kan. 595, 256 P. 963 (1927). Sometimes architects guarantee that their plans will be completed to the "satisfaction" of their clients. Gould v. McCormick, 75 Wash. 61, 134 P. 676 (1913).

151 Looker v. Gulf Coast Fair, 203 Ala. 42, 81 So. 832 (1919) ; Bayshore Dev. Co. v. Bondfoey, 75 Fla. 455, 78 So. 507 (1918) ; Bodin v. Gill, 216 Ga. 467, 117 S.E.2d 325 (1960); Kortz v. Kimberlin, $158 \mathrm{Ky} .566,165$ S.W. 654 (1914); Coombs v. Beede, 89 Me. 187, 36 A. 104 (1896); Bayne v. Everham, 197 Mich. 181, 163 N.W. 1002 (1917); Gaastra v. Holınes, 36 N.M. 175, 10 P.2d 589 (1932) ; Ressler v. Nielson, 76 N.W.2d 157 (N.D. 1956); Wills v. Black \& West, Architects, 344 P.2d 581 (Okla. 1959); Smith v. Goff, 325 P.2d 1061 (Okla. 1958); White v. Pallay, 119 Ore. 97, 247 P. 316 (1926); Follansbee Bros. Co. v. Garrett-Cromwell Eng'r Co., $48 \mathrm{~Pa}$. Super. 183 (1911); Surf Realty Corp. v. Standing, 195 Va. 431, 78 S.E.2d 901 (1953).

152163 Iowa 620, 145 N.W. 277 (1914).

153163 Iowa at 622,145 N.W. at 278. A few other cases have used warranty language on facts justifying a finding of negligence. See Nave v. McGrane, 19 Idaho 111, 128-29, 113 P. 82, 88 (1910); Leinhard v. Meyer, 11 La. App. 328, 123 So. 130 (1929).

154 See W. SAdLER, supra note 5, at 202; Note, 34 TuL. L. REv. 634, 636 \& n.12 (1960).

155219 S.C. 263,64 S.E.2d 885 (1951). The case actually did not involve an architect. It involved a Frigidaire dealer who designed frozen-food locker facilities but the court relied on architect cases and treated the designer as if he were an architect. See id. at 271,64 S.E.2d at 888 .

156 Id. at 271,64 S.E.2d at 888 . 
ing the well settled principle enunciated in other cases that where an architect's client furnishes the architect's plans to a contractor the client warrants their sufficiency. ${ }^{167}$ The only effect of this "warranty" is to estop the client fronl recovering against the contractor for defects arising from the architect's plans. ${ }^{158}$ This does not mean that the architect warrants the sufficiency of his plans in his role as an independent contractor to either the client or the contractor. $\mathrm{He}$ is liable only if he has been negligent. A failure to distinguish the client's warranty to the contractor, which courts almost uniformly impose, fron the architect's warranty to contractor or chent, which courts virtually never impose, led the Hill court into judicial error. This kind of faulty analysis is not compelling precedent for imposing strict liabilty on architects.

In a sense many architects today impose partial strict liability upon themselves by voluntarily correcting some of their nonnegligent defects. ${ }^{160}$ However, not all architects correct such nonnegligent mistakes. Moreover, chance often determines whether the client will bear the burden of defects by himself, because an architect does not advertise that he corrects nonneghigent defects, nor does the client ask about this before he sigus a contract. Even if an architect does correct nonnegligent mistakes, he judges for himself whether he has made a mistake causing the defect. No matter how honest the architect, a jury is a more objective arbiter. Most importantly, the architect may correct the defect but will probably not compensate the client for consequential injury to the rest of the structure, nor for resulting personal injury to himself or third persons. ${ }^{100}$

Strict liability is not imposed by the courts today, and voluntary payments are not adequate. Other means of shifting and spreading loss presently available must be examined.

\section{Liability of Building Vendors and Manufacturers}

Very recently, warranties lave been applied to the builder-vendor of

157 E.g., Montrose Contracting Co. v. County of Westchester, 80 F.2d 841 (2d Cir. 1936) ; Penn Bridge Co. v. City of New Orleans, 222 F. 737 (5th Cir. 1915); Roth v. Great Atl. \& Pac. Tea Co., 108 F. Supp. 390 (E.D.N.Y. 1952) ; Armstrong Constr. Co. v. Thompson, 64 Wash. 2d 191, 390 P.2d 976 (1964); Ericksen v. Edmonds School Dist. No. 15, 13 Wash. 2d 398, 125 P.2d 275 (1942).

158 The contractor may rely on the plans and specifications at least where they are not "so apparently defective that an ordinary builder of ordinary prudence would be put on notice that the work was dangerous." Roth v. Great Atl. \& Pac. Tea Co., 108 F. Supp. 390, 394 (E.D.N.Y. 1952). Accord, Penn Bridge Co. v. City of New Orleans, 222 F. 737 (5th Cir. 1915).

159 Letters from 25 Architects to Jeff Sobel, on file with the California Law Review. Ten architects claimed they always rectified nonneghigent mistakes, if brought to their attention, as a matter of good business practice; twelve often did so; two seldom did so; one never did so.

100 Cf. Prosser, The Assault Upon the Citadel, 69 Yaxe L.J. 1099, 1120 (1960). 
homes, ${ }^{161}$ but they are not an adequate substitute for strict liability for architects. The warranty imposed is really strict liability in tort. ${ }^{\mathbf{1 6 2}}$ According to the hoary maxim that caveat emptor applies to the sale of completed structures, this warranty is usually applied only where the structure is sold before completion. ${ }^{163}$ The warranty imposed requires, regardless of negligence, that the home when completed "shall be reasonably fit for the purpose intended."164 So the contractor who builds and sells structures is caught in the trend toward strict liability.

Even apart froin its limited scope, this part of the present system of safeguards is inadequate for two reasons. First, it requires the vendor, as the architect's client, to bear the loss for a lome which is unfit due to a nonnegligent error by the architect. Although mass vendors of houses ${ }^{165}$ may be able to spread the loss as efficiently as architects, small home developers or vendors who invest in a single office building cannot do so. Second, protections afforded by vendor warranties do not aid persons dealing with the architect directly in order to have a lome or other building designed for their use.

Under products liability doctrine, loss can be shifted from the client or third persons to the manufacturer of defective material used in the structure, subject to applicable limitations on strict hability for suppliers of chattels. However, this protects the client and third persons from only a small proportion of possible damage; damage from erroneous plans or specifications not involving defective materials is not covered at all.

\section{Client Protection by Contract}

Much of the need for imposing strict liability on architects could theoretically be inet by specific provisions in the architect-client contract. ${ }^{166}$ The client could insist on a provision making the architect

161 See, e.g., Glisan v. Smolenske, 153 Colo. 274, 387 P.2d 260 (1963); Weck v. A:M Sunrise Constr. Co., 36 Ill. App. 2d 383, 184 N.E.2d 728 (1962); Jones v. Gatewood, 381 P.2d 158 (Okla. 1963); Golin v. Sgrignoh, 83 Dauph. 331 (Pa. C.P. 1965); Hoye v. Century Builders, Inc., 52 Wash. 2d 830, 329 P.2d 474 (1958).

162 See Schipper v. Levitt \& Sons, 44 N.J. 70, 95, 207 A.2d 314, 328 (1965).

163 See Mitchem v. Johnson, 7 Ohio 2d 66, 72, 218 N.E.2d 594, 597 (1966).

164 Harrison v. Heagy, 81 Dauph. 7 (Pa. C.P. 1963), aff'd, 82 Dauph. 19 (Pa. C.P. 1964).

165 For example, the defendant in Schipper v. Levitt \& Sons, 44 N.J. 70, 207 A.2d 314 (1965).

166 Clients could also seek to protect themselves by inspecting for potential danger spots, or by hiring someone to do this inspection for them. But even if the duty of hiring an examiner at high cost, Bearman, supra note 95, at 545, was placed on the client, many trouble spots-for instance a weakness in the foundation or roof-would still not be discoverable. $I d$. In adddition, if a defect reducing the value of the structure were discovered before it could injure other property or persons, then, absent neghgence, the architect would not be liable today for any reduced value of the defective part of the structure itself because lie is ouly liable for defects and damages caused by his negligence. 
strictly liable for personal injuries or property damage caused by his work. This theoretical possibility is an inadequate substitute for strict liability in three ways. First, persons other than the client could not recover. The client has hittle incentive to insist, for example, on contract protection for later owners of the home. Second, nothing indicates that individual clients lrave sufficient bargaining power to insert such a provision in the contract. As long as most architects continue to use the American Institute of Architects standard form contracts, ${ }^{107}$ which do not make the architect guarantor of his plans, clients have no real control over contract terms. ${ }^{168}$ Third, even if clients could impose sucls a provision, most of thein are unaware of its necessity. Before requesting such a provision, the client must consider the possibility of errors on the architect's part, realize the limited extent of the architect's liability for such errors, and judge the danger great enough to merit contract protection. In fact, the client probably just assumes that the architect's plans will not be defective. The law slould protect these "thoughtless" clients from their own lack of foresight. In accord with the humane spirit behind the trend toward greater compensation, illustrated by imposition of strict liability in other areas, loss should be shifted from the chent's shoulders and spread so that no one person will be severely damaged..$^{100}$

\section{Insurance}

Clients and third persons may insure against loss themselves. If this were done, the loss would be spread and there would be little reason to impose strict liability on architects. As a practical point, however, client's and third person's insurance today does not cover most losses due to an architect's nonnegligent mistakes. ${ }^{170}$ Moreover, there are several reasons why the burden of acquiring insurance protection should be put on the architects by imposing strict liability.

The architect whose mistake has caused the loss should buy insurance to pay for it. Losses will only be spread througl insurance if those bearing the loss are likely to be insured. It is more likely that architects, as professionals, will insure against liability, than that clients or third persons will insure against the risk of injury or loss. Architects can easily spread the loss through insurance, because any one loss is spread

${ }^{167}$ See Letters from 25 Architects to Jeff Sobel, Oct. 1-Nov. 1, 1966, on file with the California Law Review.

188 Cf. Henningsen v. Bloomfield Motors, Inc., 32 N.J. 358, 161 A.2d 69 (1960).

160 The situation of vendor warranties, see note 135 supra, is analagous. The vendee could try to secure a warranty from the vendor but the law protects the vendee in tort despite this theoretical possibility.

170 See Fassino, Homeowner-Know Thy Policy, Wis. B. Ass'N BurL., Dec. 1964, at 48, 54-55; cf. ArceITECTURAL PRACTICE supra note 6, bk. I, § 3.05 . 
among many clients. The insurance company spreads the cost of paying the loss to all architects insuring with it; an individual policy's cost is spread among all of an architect's clients.

Ideally, then, architects could and would insure to spread the loss resulting from their mistakes if strict liability were imposed on them. Although a sudden imposition of hability on architect's might create practical problems, existing insurance practices indicate that such problems would be minor and that insurance would in fact be available. Many architects already have liability insurance which has been available to them for over a decade. ${ }^{171}$ Present liability insurance covers negligent errors and nonnegligent errors and omissions for which the architect has become legally liable. ${ }^{172}$ However, no payments are made today for nonnegligent errors for which architects are not legally liable. If architects were held strictly liable, the insurance company would be obligated to pay for nonneghigent errors under existing policies. There is little reason to believe that the insurance companies would cancel the availability of insurance or restrict coverage to negligent acts only, if strict liability were imposed on architects. Increased claims might mean a temporary net loss for the insurer, but new claims data would probably lead to a readjustment of premiums so that a gain could be realized. ${ }^{173}$ Those architects not presently insured could insure in the future to guard against the costs of strict liability and could even protect themselves for nonneghigent errors and omissions occurring before the coverage is obtained if the error is discovered after the insurance is purchased. ${ }^{174}$ Today the cost of insurance is passed on to the public, representing anywhere from five-hundredths of one per cent to one per cent of the architect's fee. ${ }^{175}$

171 See Letters from 25 Architects to Jeff Sobel, on file with the California Law Review. Thirteen of twenty-five architects had liability insurance. Professional liability insurance is currently offered by the following companies: The American Home Group, American Universal Group, Citizens Casualty Co. of New York, Commercial Standard Insurance Co., Firemen's Fund, Olympic Insurance Co. Letter from Frank Serpa, Commercial Sales Development Manager, Allstate Insurance, to Jeff Sobel, Nov. 7, 1966, on file with the California Law Review.

172 See Continental Casualty Co.'s Architects' Professional Liability Policy, Continental Casualty Co., on file with the California Law Review.

173 Cf. White, Professional Liability Insurance, 45 ANs. INST. of ARCHItEcrs J. 47, 50-51 (1966) (discussing such a course of events when architects were exposed to greater hability as privity rules were relaxed).

174 Retroactive clauses are available in present policies. See Smay, A NEw Look AT Professional Liabitity Insurance, 26 Am. Inst. of Architects J. 455, 456 (1957); Continental Casualty Co.'s Architects Professional Liability Policy, on file with the California Law Review.

175 Letters from 25 Architects to Jeff Sobel, Oct. 1-Nov. 1, 1966, on file with the California Law Review. Depending on the number of years the architect has been in business and other factors, the cost of a policy with a $\$ 200,000$ limit on recovery is between $\$ 470-\$ 570$ a year, and a policy with a $\$ 250,000$ limit costs approximately $\$ 800$. Id. 
Even a doubling of this cost which might result from imposing strict liability does not seem unduly burdensome.

\section{Meeting the Objections Against Strict Liability For Architects}

Earlier in this Comment arguments for extending strict liability to architects were discussed. ${ }^{178}$ It must now be demonstrated that the disadvantages flowing from this extension would not outweigh the advantage of spreading the loss.

\section{Lawesuits Will Damage the Professional Reputation of the Architect}

Fear of tarmshing professional reputations clearly has been the main reason for insulating doctors, lawyers, architects, and engineers from strict liability. ${ }^{177}$ One tort expert commented on the different treatment accorded professional men and suppliers of chattels: "The reason for this disparity is not far to seek, for, despite almost universal liability insurance, the courts are as ever alive to the weighty repercussions of adverse verdicts on the reputation and future of professional defendants, and have shown hittle inclination to condone attenuations of the fault requirement, however tempting the analogy with enterprise liability in the business world."178

Weighing the loss of professional reputation against the expected benefits of strict liability clearly requires a value judgment. One must first ask how much loss in reputation would result from strict liability. The loss would vary with the number of strict liability cases tried. Arguably, fewer cases will be tried under strict liability. The presence of insurance would mean in many cases that a claim "could be quietly and satisfactorily settled by an insurance adjuster."170 Further, defendants might contest fewer cases under strict liability, questioning the worth of disputing the usually minor issues of whether they caused the damage, or whether the damage followed an unreasonable creation of risk, ${ }^{180}$ or whether the structure was seriously reduced in value in the judgment of a reasonable man. ${ }^{181}$

Even assuming a significant increase in lawsuits under strict liability, one can only guess at the actual loss in reputation accompanying such suits. Since no study has measured the impact of lawsuits on professional

176 See text accompanying note 159-70 supra.

177 See Witherspoon, supra note 4 . "[A] law suit against . . . an architect . . . might ruin his future business reputation with his public." Id. at 137.

178 Fleming, Developments in the English Law of Medical Liability, 12 VAND. L. REv. 633, 634 (1959). Fleming's article deals specifically with doctors but his comment on the argument against strict liability obviously applies to all professional men.

179 Witherspoon, supra note 4 , at 137.

180 See discussion of the formula for determining the types of damages for which the architect will be strictly liable in text accompanying notes 134-48 supra.

181 Id. 
reputation, ${ }^{182}$ such an assessment is somewhat speculative. Lawyers may exaggerate the degree to which the world watches the activity of the courts. For most people, a lawsuit against an architect would probably pass unnoticed unless publicized over television. Most people hearing of the suit from other sources would be in the building industry and would know the architect was being sued under strict liability and not for acting unreasonably.

Advocacy of strict hability for architects does not necessarily imply advocacy of strict liability for all professions. Suits against architects would probably attract less notoriety than would suits against doctors and attorneys. The confidential relationships involved in the latter professions ${ }^{183}$ seem to elevate them in other men's eyes; suits against people in such positions might well attract more attention than suits against an architect. Further, the close relationship of medicine to human hife indicates that a doctor's negligence would be more newsworthy than would that of other professionals. The reputation lost in lawsuits agamst professional men may be overestimated by those opposing strict hability, and the problem seems less severe with architects than with attorneys and physicians. There is little chance that potential clients will hear of a lawsuit against an architect and thereafter regard him as less qualified. The highly speculative injury to professional reputation due to cases not settled quietly should not be a compelling factor in weighing the benefits of strict liability against possible undesirable effects.

\section{Because the Architect's Judgment is Involved, Errors are Inevitable}

Because there is much less certainty in architectural design than in manufacturing a product, the architect is expected to make more errors in exercising his judgment concerning many variables. Although some errors are inevitable, the conclusion that the architect should therefore not be strictly liable ${ }^{184}$ is misguided. Someone must bear the loss for inevitable mistakes of judgment, and strict architect's liability distributes the loss most equitably.

\section{Architects Would Either Grow Careless or "Too Careful"}

It might be suggested that the architect's incentive to be careful would disappear if he were liable for defects regardless of negligence. ${ }^{185}$

$182 \mathrm{~A}$ study is warranted. "The field of law is . . . . for scientific study analogous to the field of any other science." Bingham, What is the Law, 11 MICH. L. Rev. 1, 11 (1912). A study could survey groups of the population to see how inany people have heard of certain cases involving professionals, and then question those who have heard of the case in depth to determine their attitude toward the suit.

183 White, supra note 173 , at 47-48.

184 See Broyles v. Brown Eng'r Co., 275 Ala. 35, 39, 151 So. 2d 767, 771-72 (1963)

(dictum); cf. Walter v. England, 133 Cal. App. 676, 686, 24 P.2d 930, 934 (1933).

185 Cf. 2 F. HARPER \& F. JAMIES, supra note 97, \& 13.5, at 771-72 (1956). 
The answer to this objection is clear: "[F]ear of legal liability is not the only thing that spurs a man to be careful."186 Simple professional pride and fear of disapproval from associates for a job poorly done would promote care. Since insurance premiums are based on the claim record of the insured, ${ }^{187}$ the typical architect will be financially motivated not to lower his standard of care, because, of course, architects will be liable not only for claims due to strict liabihty but those due to carelessness as well.

Perhaps a desire to reduce mistakes of judgment once strict liability is imposed would lead to reduced creativity in custom design and a trend toward standardized design. However, it is doubtful that a creative custom designer, protected by insurance, would be restrained by the threat of slightly higher insurance rates. Moreover, this argument has little relevance for most architects today who deal in fairly standardized work. Most importantly, some sacrifice in "creative activity" seems justified to obtain the benefits from the imposition of strict liability.

\section{The Architect Should Not Be Strictly Liable for the Consultant's Errors}

Holding an architect strictly liable for his consultant's nonnegligent errors might be considered unfair. However, an architect held liable for such errors will not suffer personally because he will pass the cost on to his clients through insurance. In addition, no greater client protection would be afforded by also holding the consultant strictly liable. Because the consultant's errors are incorporated into the plans, holding the architect strictly hable ${ }^{188}$ for all errors in the plans protects all those injured by the consultant's errors. Consultant's insurance would protect precisely the same class of people as architect's insurance. ${ }^{180}$ Moreover, if consultants were held strictly liable, each consultant would simply pass the higher cost of his insurance on to the architect. The class of people ultimately bearing the costs of insurance would still be the architect's clients. Thus, strict liability for the architect's consultants apparently has no advantage. Furthermore, if only the consultant were held strictly liable for his nonnegligent errors, wasteful litigation would

186 Id. at 772 .

187 Letter From A.M. Carpenter, Professional Liability Division of Victor O. Schinnerer \& Co., to Jeff Sobel, Nov. 23, 1966.

188 The architect is often already "strictly liable" today through the doctrine of respondeat superior if the consultant has been negligent. See note 75 supra.

189 Cf. Montgomery v. Goodyear Tire \& Rubber Co., 231 F. Supp. 417 (S.D.N.Y. 1961); Goldberg v. Kollsman Instrument Corp., 12 N.Y.2d 432, 191 N.E.2d 81, 240 N.Y.S.2d 592 (1963). But of. Suvada v. White Motor Co., 32 Ill. 2d 612, 210 N.E.2d 182 (1965). 
ensue between the insurers of the architect and the consultant to prove who caused the damage, such litigation costs ultimately falling on the architect's clients.

\section{The Architect Would be Deluged with False Claims}

The fear of fictional defects under strict liability was used as an early argument against strict liability for sellers of chattels. ${ }^{100}$ This argument reflects a dim view of human nature, a lack of confidence in lawyers' ethics, and no faith in a jury's ability to distinguish genuine from illegitimate claims. Used in reference either to architects or to products liability, the argument assumes for no reason that the "fraudulent claimant, when he is inventing a defect in the product, will by choice invent one whicl does not indicate any negligence."101 The danger of false claims is no greater under strict liability for architects than under existing negligence doctrine.

\section{III}

\section{DAMAGES}

\section{A. The Measure of Damages}

The measure of damages slould be the same under both strict liability and liability for negligence. ${ }^{192}$ For personal injury and property damage the typical rules of damages ${ }^{193}$ apply to architects as to other defendants. ${ }^{104}$

When the only damage is a defect in the structure itself, courts have applied one of two measures of recovery. The client is legally liable to the architect for services rendered, but may recoup either the costs of repairmg the architect's defective work, or the difference in value between the stucture as actually completed and its value if completed correctly..$^{105}$

If the cost of correcting the defect seems disproportionate to the client's interest in getting what lie bargained for because fixing a small

100 See Prosser, The Assault Upon the Citadel, 69 YaLe L. J. 1099, 1122 (1960).

$101 \mathrm{Id}$.

102 The amount of damage to property that will be required in order to sustain recovery at all will change as between strict liability and negligence if the formula suggested by this Comment is adopted. See text accompanying notes 136-39 supra.

103 See generally W. Prosser \& Y. Smate, Cases and Materials on Torts 598-606 (3d ed. 1962).

104 See Montijo v. Swift, 219 Cal. App. 2d 351, 33 Cal. Rptr. 133 (1963). In addition to civil damages an architect who has been "incompetent" or "grossly negligent" inay lave lis license revoked. Kuehnel v. Wisconsin Registration Bd. of Architects \& Professional Eng'rs, 243 Wis. 188, 9 N.W.2d 630 (1943).

105 Housing Authority v. Ayers, 211 Ga. 728, 88 S.E.2d 368 (1955); Nieman-Irving \& Co. v. Lazenby, 263 N.Y. 91, 188 N.E. 265 (1933). 
defect would require major alterations, then the client must be satisfied with the difference in value between the structure as constructed and the structure as it should have been constructed. ${ }^{106}$ If repairing defective work does not involve disproportionate cost, then the client has the "right to have the very thing agreed upon." Even if the deviation from plans and specifications or from the client's instructions has not reduced the structure's market value the architect should provide what the client wants.

Even if the cost of correction is high, if the building is nearly worthless without it then the "cost of correction rule" is proper at least where that cost is less than the difference in value. ${ }^{108}$ In this case the architect is entitled to make good the damage he has caused in the least expensive way, and the client who gets what he actually bargained for has no cause to complain.

A more difficult situation arises when the reduction in market value is great and the cost of correction is greater. Here it seems unfair to let the architect pay the lesser amount. The chent wants his extensive damage corrected, and an award limited to reduction in market value would force the client to spend his own money to correct the architect's mistake.

A third measure of damages should sometimes be used although no cases employing it have arisen. When correction of a major defect results in a structure with diminished value, the architect should be liable for the cost of correction plus the remaining difference in value between the structure as corrected and the structure as it should have been built.. ${ }^{100}$

If a client suffers monetary loss because of an architect's negligent underestimate of cost, the measure of damage is the difference between the estimated and actual costs, less any increase in the client's income from a revenue producing structure whose value is enhanced by the additional unplanned cost. ${ }^{200}$

\section{B. Contribution or Indemnity}

The architect who has lost a lawsuit or settled a claim ${ }^{201}$ for neghgent preparation of plans and specifications may seek contribution from another person whose negligence has concurred to produce the injury

106 See Bayshore Dev. Co. v. Bonfoey, 75 Fla. 455, 78 So. 507 (1918); Trunk \& Gordon v. Clark, 163 Iowa 620, 145 N.W. 277 (1914).

197 Foeller v. Heintz, 137 Wis. 169, 180, 118 N.W. 543, 547 (1908). Accord, Barraque v. Neff, 202 La. 360, 11 So. 2d 697 (1942); Schwartz v. Kuhn, 71 Misc. 149, 126 N.Y.S. 568 (Sup. Ct. 1911).

198 See Bloomsburg Mills, Inc. v. Sordoni Constr. Co., 401 Pa. 358, 164 A.2d 201 (1960) $(\$ 18,645)$.

190 See Bell, supra note 3, at 717 .

200 Capitol Hotel Co. v. Rittenberry, 41 S.W.2d 697 (Tex. Civ. App. 1931).

201 In some states it makes a difference whether a defendant seeking contribution lost a lawsuit or settled out of court. W. Prosser, supra note 11, $\$ 477$, at 277 . 
for which the architect must pay. ${ }^{202}$ For example, an architect who has negligently incorporated a consultant's negligent error into the plan package may sue the consultant for contribution. If negligently prepared plans are blatantly defective, a contractor building in rehance on the architect's plans is negligent ${ }^{203}$ and a good candidate for a contribution suit. Moreover, if a landlord with a duty to repair defects in the premises in his control negligently fails to do so, the architect sued for that negligently created defect should be able to sue for contribution. Of course, the architect himself miglit be sued for contribution by a consultant, contractor, or landlord forced to pay for damages due in part to the architect's neghigence. General rules of contribution for tort actions should govern these cases. Depending on the jurisdiction, actions for contribution may or may not be allowed. ${ }^{204}$ Rules of contribution vary in inany ways, including, for example, whether one asked to contribute must have been a party to the earlier suit. ${ }^{205}$

The same general rules should apply to an architect seeking contribution after being held strictly liable. Although the rules are the same, the strict hability fact situation will make it difficult, if not impossible, for the architect to find another tortfeasor wlrose nonnegligent act, for which he is held strictly hable hike the architect, has concurred to produce the imjury. For example, the architect may be held strictly liable for nonnegligently incorporating a consultant's nonnegligent error into the plans. The consultant will probably not be strictly liable ${ }^{206}$ and therefore the architect will stand as the only tortfeasor. In addition, since the architect's error was nonneghigent, it is unlikely that a contractor relying on the plans will be found negligent for doing so. ${ }^{207}$ The

202 Of course it may be the architect's insurance company that brings the suit if it was the insurance company that has paid for the loss. The courts draw no distinction between the actual tortfeasor and his insurance company asking for contribution. Silver Fleet Motor Exp. v. Zody, 43 F. Supp. 459 (E.D. Ky. 1942); see State Fann Mut. Auto Ins. Co. v. Continental Cas. Co., 264 Wis. 493,59 N.W.2d 425 (1953).

203 See Penn Bridge Co. v. City of New Orleans, 222 F. 737 (5th Cir. 1915); Roth v. Great Atl. \& Pac. Tea Co., 108 F. Supp. 390 (E.D.N.Y. 1952).

204 Six states allow contribution on the basis of court decisions. W. PROSSER, supra note $11, \S 47$, at 274-75. Twenty-one states allow contribution on the basis of statute. See Note, Adjusting Losses Among Joint Tortfeasors in Vehicular Collision Cases, 68 YaLE L.J. 964, 981-82 (1959). Twenty-three states, following the old common law rule, apparently allow no contribution.

2051 F. HARPER \& F. JaArES, supra note 97 , 10.2 , at 720; W. Prosser, supra note $11, \S 47$, at $276-78$.

206 See note 188 supra and accompanying text.

207 Cf. Montrose Contracting Co. v. County of Westchester, s0 F.2d 841 (2d Cir. 1936); Penn Bridge Co. v. City of New Orleans, 222 F. 737 (5th Cir. 1915); Roth v. Great Atl. \& Pac. Tea Co., 108 F. Supp. 390 (E.D.N.Y. 1952) ; Armstrong Constr. Co. v. Thompson, 64 Wash. 2d 191, 390 P.2d 976 (1964); Ericksen v. Edmonds School Dist. No. 15, 13 Wash. 2d 398, 125 P.2d 275 (1942). 
architect's clients will probably therefore bear his loss-i.e., the cost of his insurance-through higher fees.

The architect liable for neghigent plans is most apt to seek indemnity from his consultant. ${ }^{208}$ When a nonnegligent architect is lield liable for his consultant's negligence because the latter is found to be his agent rather than an independent contractor, ${ }^{200}$ the arclitect slould liave a right to indemnity. ${ }^{210}$ This follows from the universally accepted principle of indemnity that "one wlio is lield responsible solely by imputation of law because of lis relation to the actual wrongdoer"211 is entitled to indemnity.

A inore difficult case arises where the consultant has made a negligent error and the arclitect negligently incorporates the defect into the plans. ${ }^{212}$ Some cases have allowed negligent tortfeasors to obtain indemnity from other negligent tortfeasors if the negligent party seeking indemnity acted "passively" and the one against wliom the indemnity suit is brouglit was "actively" negligent. ${ }^{213}$ The trick lies in defining "active" and "passive"; the cases in this area are remarkably inconsistent."14

In the above case, three factors favor the arclitect. The consultant created the defect, ${ }^{215}$ no nondelegable duty of the arclitect is involvedone with a nondelegable duty is not entitled to indemnity ${ }^{216}$ _and the architect liad no actual knowledge of the defect. ${ }^{217}$ Whether these facts differentiate the arclitect's fault from that of the consultant enougl to

208 The consultant is the prime target for an indenunity suit in this area because a contractor who negligently follows the architect's grossly erroneous plans is no nore at fault than the architect and therefore not a good target for a suit shifting all of the liability. No case involving an indemnity suit by an architect against his consultant has yet arisen, probably hecause few cases have lield the architect liable for his consultant's error. Because of the increasing use of consultants, see note 75 supra, more suits holding the architect liable for consultant errors will probably occur, and therefore suits for indenunity will probably arise. The few indemnity suits by architects that have arisen are not in the area of negligent planming at all. See, e.g., Fidelity \& Cas. Co. v. J.A. Jones Constr. Co., 325 F.2d 605 (8th Cir. 1963) (supervision).

209 See note 75 supra.

210 Cf. American So. Ins. Co. v. Dime Taxi Serv,, Inc., 275 Ala. 51, 151 So. 2d 783 (1963).

211 W. Prosser, supra note 11, § 48, at 279.

212 Cf. Scott v. Potomac Ins. Co., 217 Ore. 323, 341 P.2d 1083 (1959).

213 Southwestern Bell Tel. Co. v. East Tex. Pub. Serv. Co., 48 F.2d 23 (5th Cir. 1931); Olio Fuel Gas Co. v. Pace Excavating Co., 187 N.E.2d 89 (Ohio Ct. App. 1963); Sobel v. City of New York, 9 N.Y.2d 187, 173 N.E.2d 771, 213 N.Y.S.2d 36 (1961).

214 McKenna \& Bartler, Developments in the Law of Indemnity, Forum, Oct. 1965, 7, 22; Thornton \& McNiece, supra note 103, at 1471.

215 Cf. Chicago \& I. Midland Ry. v. Evans Constr. Co., 32 Ill. 2d 600, 208 N.E.2d 573 (1965).

216 Cf. Walters v. Rao Elec. Equip. Co., 289 N.Y. 57, 43 N.E.2d 810 (1942). curiam).

217 Cf. Earle v. City of New York, 24 App. Div. 2d 476, 260 N.Y.S.2d 670 (1965) (per 
allow indemnity ${ }^{218}$ is not clear. A court that regards the difference in fault between the architect and his consultant as insubstantial will probably label the architect's negligence "active" to justify its conclusion that no indemnity should be allowed.

The architect's greatest protection would be an agreement by the consultant to indemnify the architect if he were found hable for negligently failing to discover the consultant's negligent error. Such a contract indemnifying the architect against his own negligence would probably not be held to be against public policy.219 Unfortunately for the architect-or his insurer-there is no evidence that architects as a group have enough bargaining power vis-à-vis consultants to obtain such an agreement.

If the architect nonnegligently incorporates the consultant's negligent error, the argument for indemnifying the architect rather than letting him bear the loss under strict liability is even stronger and an indemnification agreement is even more likely to be upheld.

\section{CONCLUSTON}

Rapid clranges in the last twenty years in architect hability for preparation of plans and specifications have left the jurisdictions sadly inconsistent in the rules they apply. This inconsistency is senseless because it does not reflect differing problems within the jurisdictions. Jurisdictions still requiring privity of contract for actions against the architect after the client's acceptance of the finished structure slould join the majority of jurisdictions. States requiring an allegation of a latent defect where there is no privity in a suit against the architect should eliminate or at least modify this requirement. The changes of the last twenty years should be mere prologue for the changes still needed. "Law as an instrument for justice has infinite capacity for growth . ..."220 The growth should be in the direction of strict liability for architects.

\section{Jeff Sobel}

218 Cf. Slattery v. Marra Bros., 186 F.2d 134, 138-39. (2d Cir. 1951) (dictum).

219 Cf. Southern Pac. Co. v. Morrison-Knudsen Co., 216 Ore. 398, 418-19, 338 P.2d 665,675 (1959).

${ }^{220}$ Schipper v. Levitt \& Sons, 44 N.J. 70, 89, 207 A.2d 314, 324 (1965). 